\title{
Art of the book: a brief history of decorative book binding
}

\author{
Soma Ghosh \\ Librarian and Media Officer, Salar Jung Museum, Ministry of Culture, Govt.of India \\ Hyderabad, Telangana.Email: somaghosh1133@gmail.com
}

\begin{abstract}
This article traces the history of the fine art of decorative binding in India, Egypt, Central Asia and Europe where it was mostly prevalent during ancient and medieval times and the cross cultural influences. Early modern era too had beautiful work on binding covers. Some works have even been called 'treasure bindings' made for important people in high social positions. The book bindings are still available across libraries, museums and private collections. Great care was taken to make the binding of a revered text strong and look appealing. The ancient and medieval times craftsmen used various methods and materials like wood, leather to make the bindings and used ivory, metal and pigments for embellishment. The article briefly describes the technique of book binding and showcases some specimens of fine book covers from across the world.
\end{abstract}

Keywords: Book binding, vellum, scroll, book cover, gilt, goatskin, papyrus, history of binding, historical bindings.

\section{Art of the book: the backdrop}

'Don't judge a book by its cover..." the adage goes. However the cover and presentation of a book helps to make an initial impact on the reader; binding has a role in giving it strength to withstand handling. Though we are in the digital era and age of the Internet, publishing is now both online and offline; hybrid libraries have both types of reading and reference material in the form of manuscripts, traditional printed books and e-resources. Historically speaking there were only hard copy books in ancient and medieval times as parchment, palm leaf, papyrus and paper bound together or as scrolls.In Egypt papyrus rolls were kept in roll form bound with papyrus tape sealed with seals of Nile mud, the rolls preserved in rectangular hollows cut in wood. The decorative element in book covers and book binding has been important in bindings of yore. Ancient and medieval India had palm leaf manuscripts tied together as a book with ornate wooden covers. Combining beauty and strength has been a historical practice. In fact the works of the cover-makers and binders were no less than a fine art. One of the definitions of book binding states it as a term applied to any process for making a book by fastening together printed or un-printed sheets of paper and providing them in this compact form with a suitable covering. Book covers can be made of paper, cloth or leather. The leather bindings have longer life than paper or cloth and are more solid in appearance. Some books have been produced which are half bound in which the back may be leather and the sides, of cloth or paper. Leather binding is largely hand-done whereas machines are used for cloth boarded books. Art was created on the covers of these bindings by embellishment and specimens are preserved all over the world. Persian bookbinding had the most delicate and intricate designs including painted lacquer work. European book bindings have been

(C) AesthetixMS 2020. This Open Access article is published under a Creative Commons Attribution Non-Commercial 4.0 International License (http://creativecommons.org/licenses/by-nc/4.0/), which permits non-commercial re-use, distribution, and reproduction in any medium, provided the original work is properly cited. For citation use the DOI. For commercial re-use, please contact editor@chitrolekha.com 
influenced by Central Asian techniques but have produced some amazing work. The craft of embellishing book bindings went on to the early modern and modern era but the old methods are now less used and there is more dependence on digital designing, mechanical printing methods and some embossing with gold coloured letters for limited edition books.

\section{Book binding: modus operandi}

If we look at book binding per se, it is an artistic craft involving three processes namely, holding together the pages of a book, protecting the collection of pages and labelling and decorating the protective cover, the last step done as per requirement and taste. Binders have always used various tools for their work. A standing press is used to compress books during the process of binding. A sewing press is used for keeping the bands or cords upon which a book is sewn are kept in tension and in their proper places while the sections or sheets are sewn to them. A book binder uses a plough-knife plough, lying press and guillotine for cutting the edges of a book. A holing machine is used for perforating the covers of books. A book binder uses backing boards, cutting boards, scissors, sewing needles, a tub for paste,, brushes for applying glue, a hammer etc. for accomplishing his overall task. The various steps in book binding include folding the printed sheets, fixing margins, beating and sewing followed by rounding and cover cutting. At the beginning and end of any book are plain or coloured papers called fly leaves or end papers. One of which is pasted down to the cover of the book. The rounding process involves the binder giving a slight round curvature to the back. Backing consolidates the process and makes the rounding more regular. Cutting of the boards or side covers was the next step. Initially wood was being used for side covers which would be covered by deer's hide, silk, velvet and later leather. During covering it would be covered fully and termed whole binding, or if a strip of leather is fixed to the corners it is termed half binding. The edges of a book can be embellished in many ways. The processes employed are colouring, sprinkling, marbling and gilding. The finishing process involves methods for decorating the cover of a book. Impressing on the book cover in leaf metal, mostly gold or silver, are various designs of an ornamental character. Metal can be superimposed on the book-cover, ivory has also been used in older books. Gilding was the most common form of decoration. Finishing has always required artistic ability, skill and fine taste.

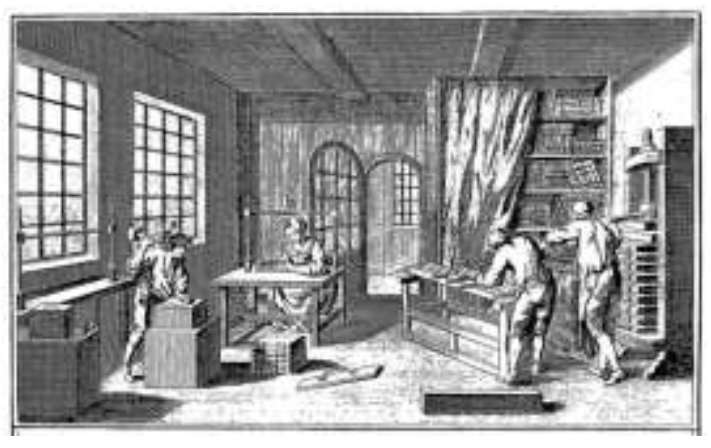

Figure 1: Book-bindery, 18th c. France.

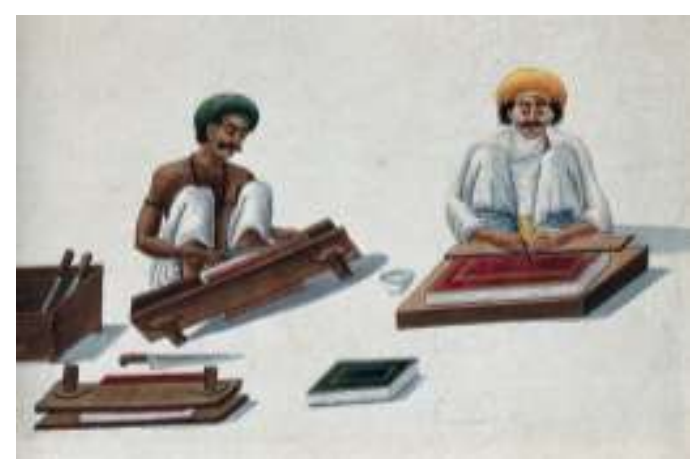

Figure 2: Book-binders, early 19th c. India.

\section{Book binding: history of a decorative art}

The history of decoration in book binding can be traced to ancient times. It has developed and undergone changes over time with many stages in the chequered history of humankind. Starting from when books started appearing in codex form or as a numbered collection of pages for easy location of content. A codex evolved when matter was written down on scrolls and wax tablets started being hinged together along a single edge. A set was called a codex in ancient Rome. During the ist century A.D. notebooks came to be written upon. Codices were easier to handle than papyrus or vellum scrolls and have been found in Egypt at Nag 
Hammadi. Papyrus is derived from a plant which grew in Egypt and was used up to the 7th and the 8th centuries; later animal skins were made into parchment or vellum which was used for manuscripts. In Egypt priestly text was written on scrolls and papyrus books. In Greece and Rome wax tablets, scrolls, parchment and papyrus was in use for writing. The codex is the precursor of the book and is attributed to the Coptic Church. The early Christians took this technique from Egypt across the world. The Islamic world used the codex to record and share the Holy Quran. However the craft of decoration in book binding might have had its origins in ancient India where sutras or religious texts were written on palm leaves cut into two and given numbers, with two long twines threaded through each and through wooden boards; forming a 'book' of palm leaves. This format was carried by Buddhist monks to ancient Gandhara (now in Afghanistan) and China. The Japanese started book binding from the 8th century. Their methods of stitching were unique and the stab binding technique was well accepted. Paper making techniques originated in China and came to Europe in the 12th century. It is mentionable here that by 300 A.D wax tablets and scrolls were replaced by papyrus and vellum codex style books. From the $5^{\text {th }}$ century books were bound between hard covers with pages from parchment, sewn onto strong cords that were attached to wooden boards covered with leather. One of the oldest book cover available for the world to see is the St. Cuthbert Gospel in the British Library, London from late 7 th century or early 8th century. It has a raised pattern and coloured tooled design (Figure 6). In the $9^{\text {th }}$ or $10^{\text {th }}$ century in Egypt wooden book binding was prevalent with inlaid ivory design. Paper was made from rags and used instead of vellum from the 15th century in Europe. Early medieval and medieval codices had flat spines but by the 15th century books started having rounded spines, the wooden covers of books are secured with clasps or straps. 7 th to 16th century illuminated manuscripts were highly revered and had fine calligraphy and binding covers which used jewels and carved ivory for decoration.

In the Indian subcontinent first there was writing on stones, clay tablets, metal, palm leaves, birch bark and then loose paper folios. Palm leaf was used as material for writing in the Indian sub-continent between 11th and 14th centuries, later to be replaced by paper. The loose sheets of palm leaves were secured between two boards called palakas. The leaves kept between two wooden covers; the leaves and cover had a silk or cotton string going through them which was tied around. The whole arrangement was kept in a cloth and called pothi. Frequently these covers were painted; prior to 11th century nothing has survived the ravages of time. In Eastern India, painting and writing on the theme of Mahayana Buddhism was popular. The Jataka tales were often depicted on the covers. Western India had covers for the Jaina manuscripts made of palm leaf with the covers painted in wood with themes from Jainism. Paper was known in India by the 12th century and by the later part of the 14th century it started replacing palm leaf and book covers started to be made of paper too. The Mughal period saw the craft of bookbinding with paper board and leather using Persian techniques.

Ulwar or Alwar in Rajasthan was the place where the best book binding in India took place. It was due to the efforts of Kari Ahmed and his sons. Kari Ahmed had come to Ulwar from Delhi on the invitation of Maharaja Banni Singh around 1820. He was of Turkoman descent and taught by followers of the Mughal atelier. The Ulwar work has the colours painted on the boards and not inlaid, the pattern is produced by use of brass blocks and the leaf edges are also painted with coloured designs. In the Deccan, Banaganapalli lacquer work has been used for decorating book covers with Persian influence. The designs include floral patterns, geometrical motifs, figures of Deccani miniatures, colour scheme of Mughal interiors. During Qutub Shahi and Asaf Jahi rule in the Deccan book covers made by pasteboard were covered with leather having blind tooling and gold tooling, lacquer application, leather filigree, cut designs, silk, velvet and the use of perni (tin foil). 


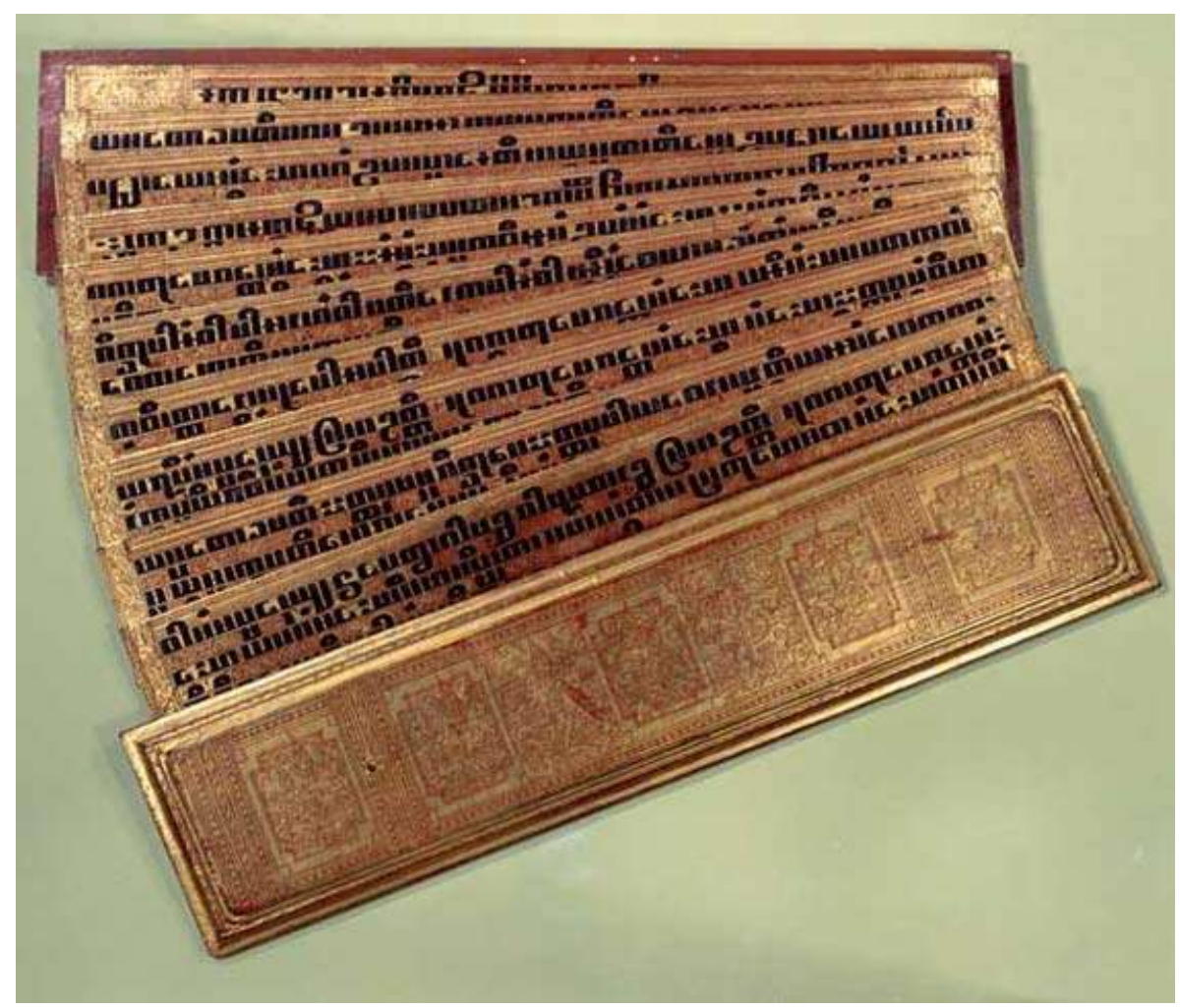

Figure 3: Pali manuscript on metal plates with ornamented wooden covers, 11th-13th century.

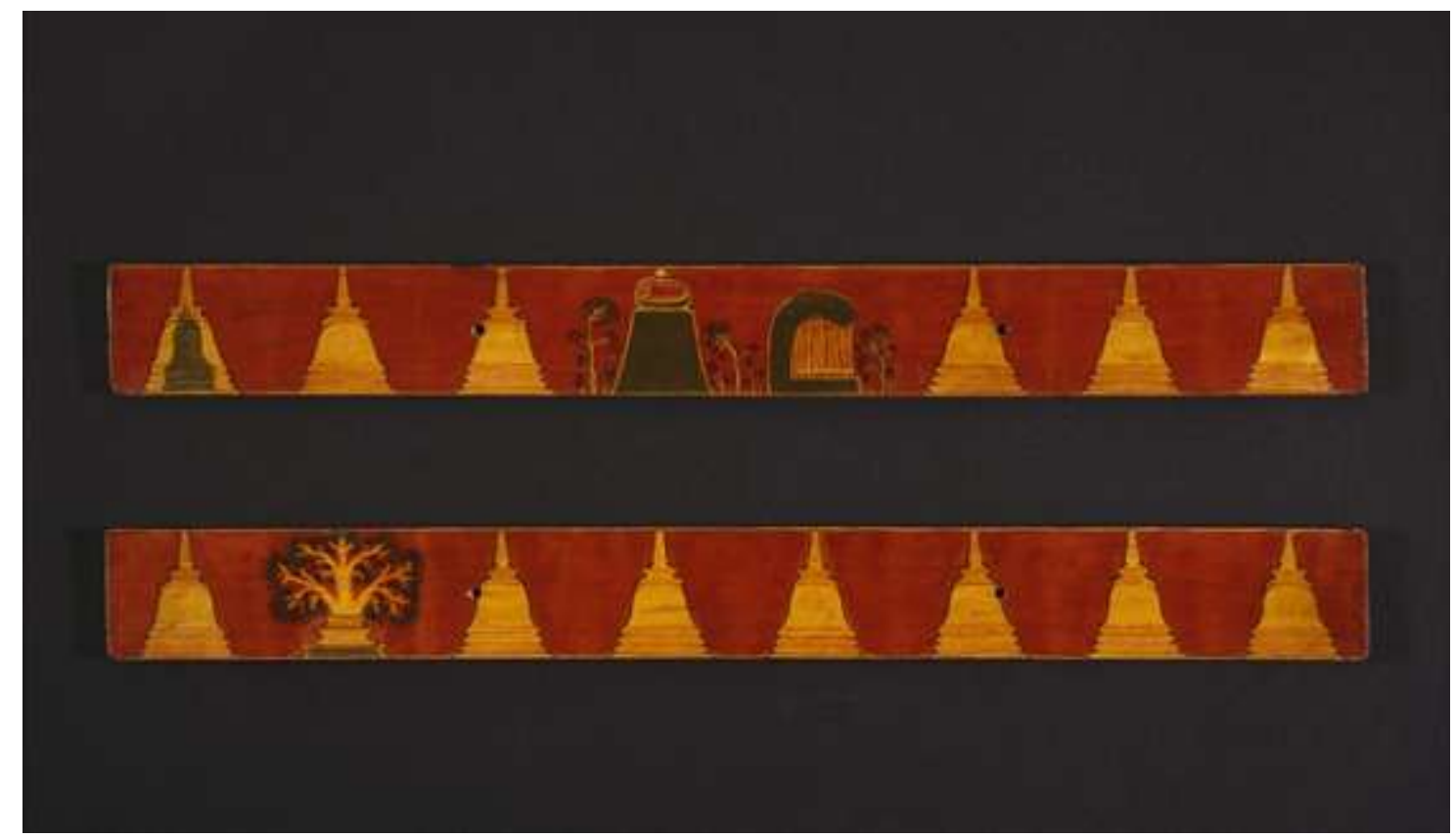

Figure 4: Palm leaf covers, 19th century, Sri Lanka. 


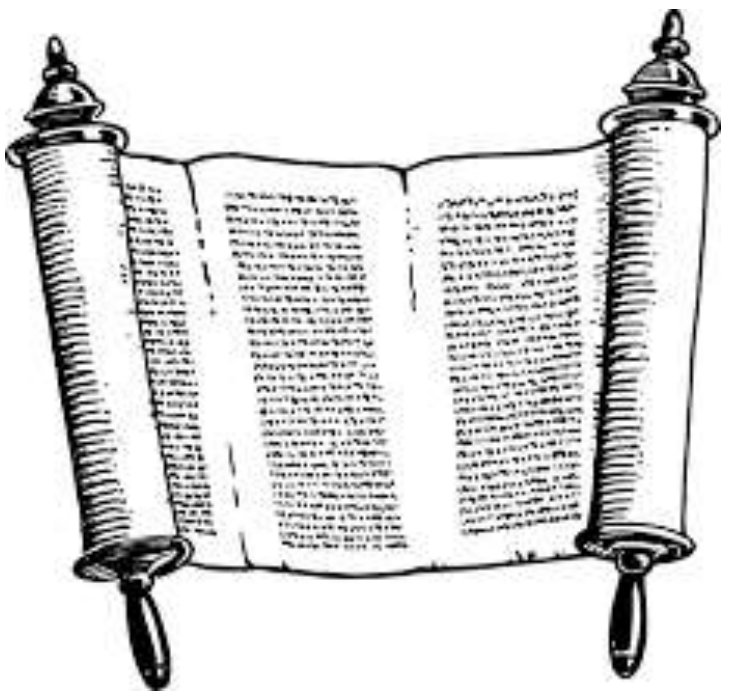

Figure 5: Egyptian papyrus scroll.

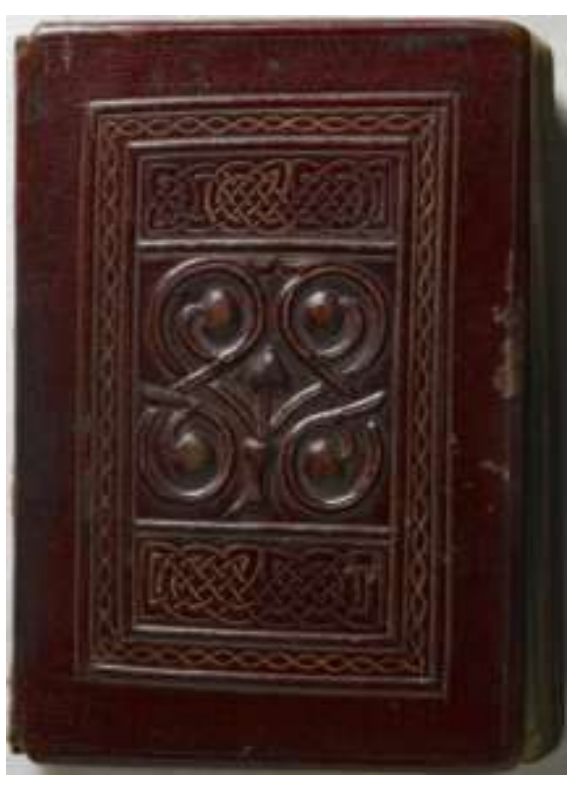

Figure 6: St. Cuthbert Gospel, late 7th century, England.

Earliest bindings were the Coptic bindings in Egypt mostly versions of the gospel written on papyrus sheets (1st to 6th century A.D), covered with leather and provided with threads to save materials used to fasten the book into a kind of parcel. Specimens of Coptic bindings of 9th to 11th century depict a variety of decorations with blind tooling and incised lines. Later works across the world until the later middle ages; 13th to 14th century were mostly abstract designs with bands, knots, arabesques and scripts. from early 15th century Persia developed extremely delicate techniques, craftsmen at Herat made splendid filigree leather and gilded work, cut paper work and deep blue painted ground for the doublures. The patterns included landscapes with animal figures, floral arabesques and gilded motifs. The Herat artisans used a technique of miniature painting on papier mache boards under lacquer varnish also done in the 15th and 16th centuries at Tabriz and Isfahan under the Safavid dynasty. The styles are seen in the 16th and 17th century work in the Indian subcontinent too.

Most Islamic bindings had a triangular shaped flap hinged to the back cover which is tucked under the front cover which serves to protect the book. Designs are mostly geometrical with a centre panel framed by borders of varying width and covered by a drawing of interwoven ribbon work. Later decorative motifs especially an oval shield in the centre with pendants with quarter sections of the shield repeated in the corners came into vogue. Tendrils instead of geometrical configuration were also prevalent resembling natural vegetation, ending in flowers. Sculptured design backed by colour also existed. The interiors of Egyptian binding were covered with a sheet of leather decorated with arabesque design or with silken material. Persian book binding of the $16^{\text {th }}$ century displayed rich design with use of medallions and spandrels, landscape and motifs etc. The interior of the covers showed filigree network decoration sculpted on the leather with a knife. This was further enhanced with gold paint. Persian craftsmen worked in the Osman empire and book decorators, calligraphists, miniaturists and book binders were employed in important cities of Turkey since the $15^{\text {th }}$ century esp. in Broussa, Adrianople and Istanbul. The Turks had too learnt the craft and many works were produced in Turkey. The typicality of these works were the existence of a double application of the same matrix to the gold printing of the outer cover, lays open to detection by a horizontal line passing through the centre. Paper instead of leather was used for decoration of the interiors. The book binding process is called mujelit and the binder mujelid 
in Turkey. The advent of printing increased the number of books produced. Mass produced books do not usually have too much decoration on their covers. Decorating a binding of a book has always been an exclusive art.

Oriental lacquer binding is a Persian invention which uses leather for the back of the binding and the front cover is made of rough paper waste pasted together, covered with a ground of chalk on which are layers of transparent lac on which the drawing is made in watercolor and a final top layer is used to carry the gold and silver. This was mostly done in $16^{\text {th }}$ century in the Safavid era. The lacquer book binding depict images of animal groups, naturescapes, flower sprays and gold arabesque patterns. The lacquer book bindings in $18^{\text {th }}$ and $19^{\text {th }}$ centuries preserved the tradition to a large extent, though the earlier binding were richer in colour and composition. In Figure 13 the dark brown goatskin binding with central lobed medallion and pendants and doublures (an ornamental lining on the inside of a book cover) with filigree decoration may date to the 9th or 1oth century AH/15th or 16th century A.D. The Figure 13 with the flap depicts ink and pigments on dark cream laid Persian paper covered with black goatskin decorated with gold with brown leather doublures.

Decorative bindings have been made in different countries and across the centuries with qualities of strength, variety and beauty. In the following figures some unique bindings are enlisted and showcased for a clearer understanding; while tracing more history of decorative book binding. Figure 7 is a Coptic Egyptian binding from the 8th century with goatskin, (Coptic refers to last part of ancient Egyptian civilisation) with double boards made from papyrus with leather thongs at the top and bottom and three on the front edge of the upper cover and three metal rings fixed with short leather straps in the corresponding places on the front edge of the lower cover.

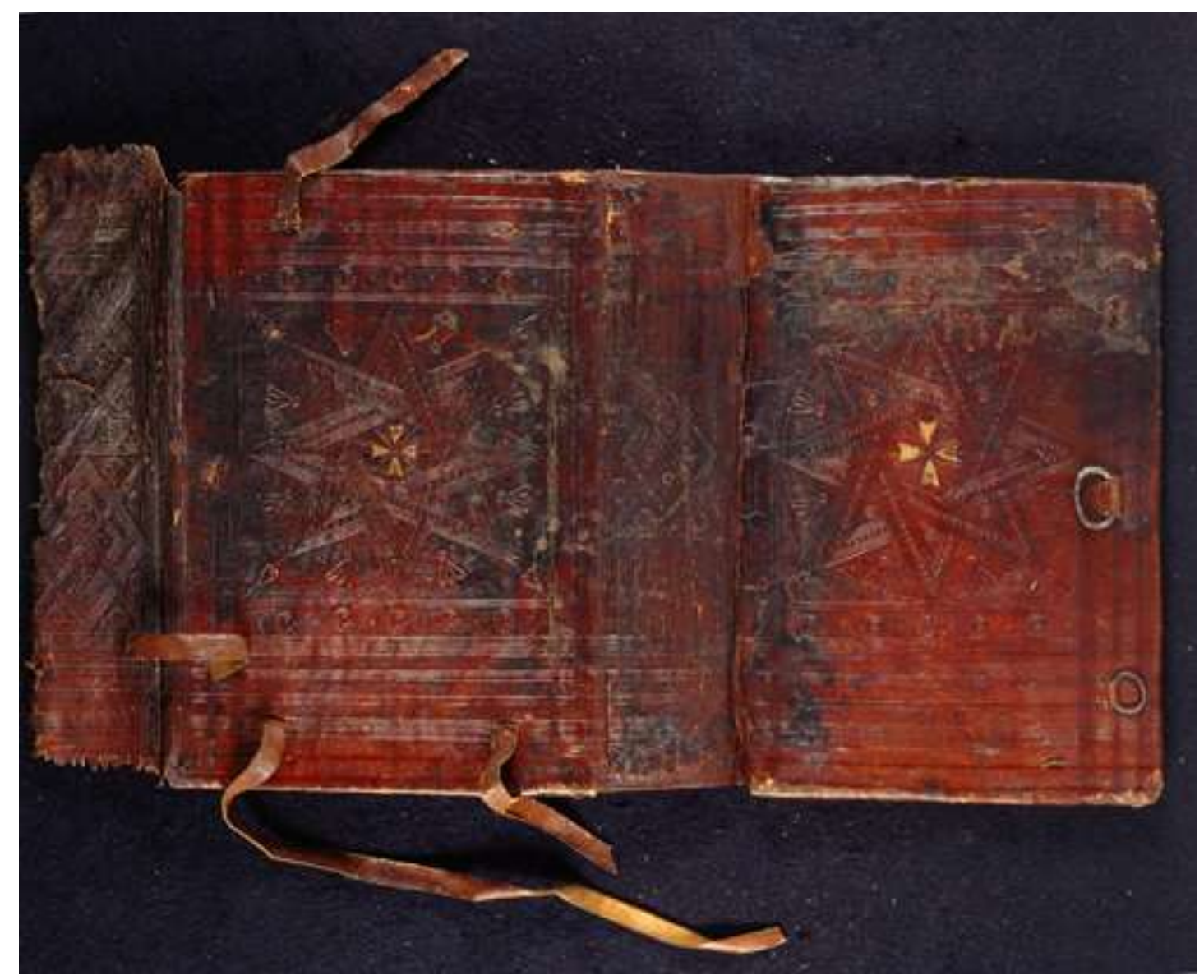

Figure 7: Egyptian binding, 8th century. 
7 | Art of the book: a brief history of decorative book binding

Figure 8 is a French binding from the 9th century with a metal cover onlaid and with jewels. Repousse silver covers on wooden boards of Christ in Majesty. Bone relics set within the oak boards seen on cover. Figure 9 is a German book binding from the 11th century rebound at England having ivory panels of crucifixion of Christ and four symbols of the Evangelists. Figure 10 is most probably an Italian binding from the 12th century, a treasure binding with ivory and jewelled covers; the book written for Melisende, daughter of Baldwin II.

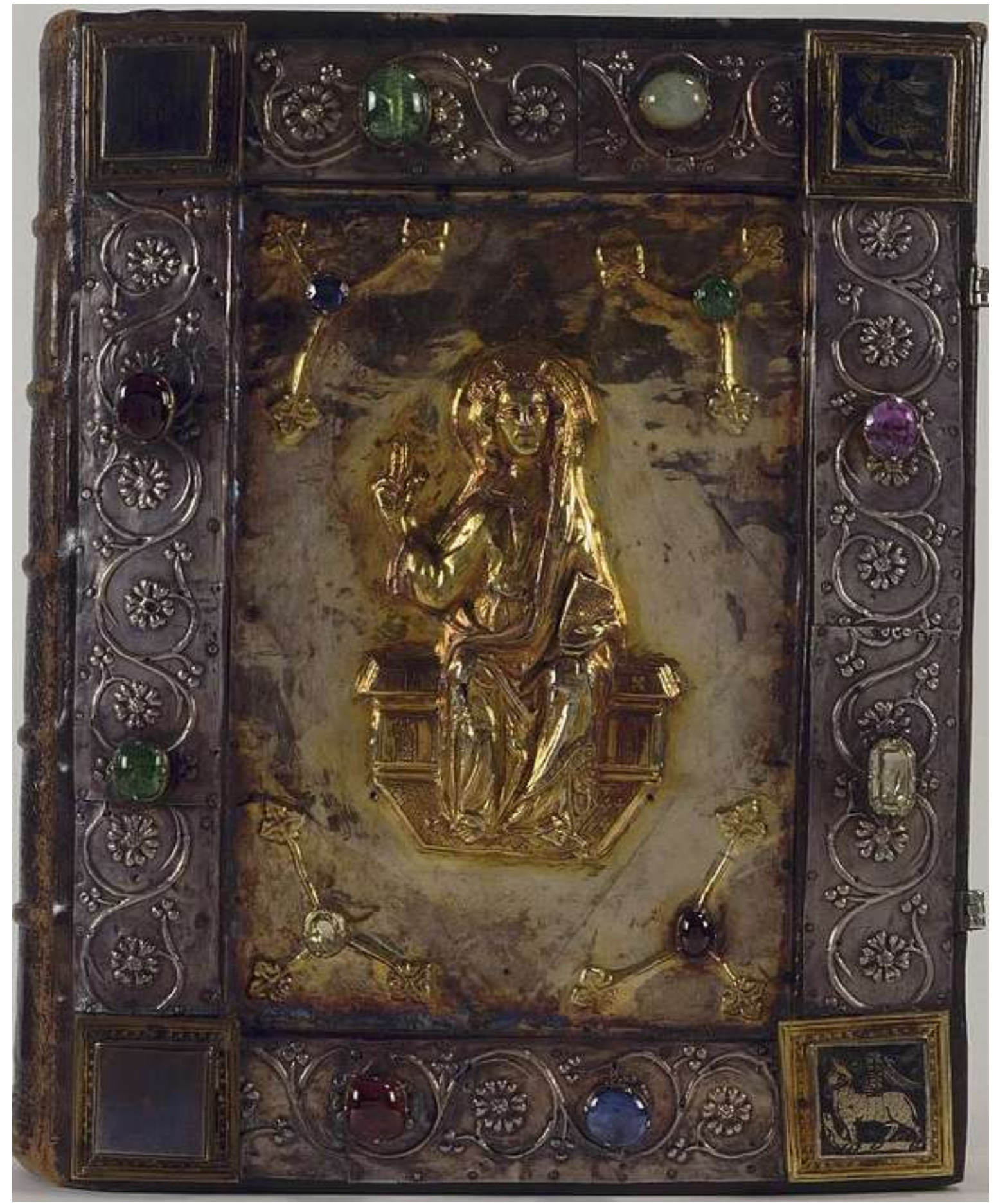

Figure 8: French binding, 9 th century. 


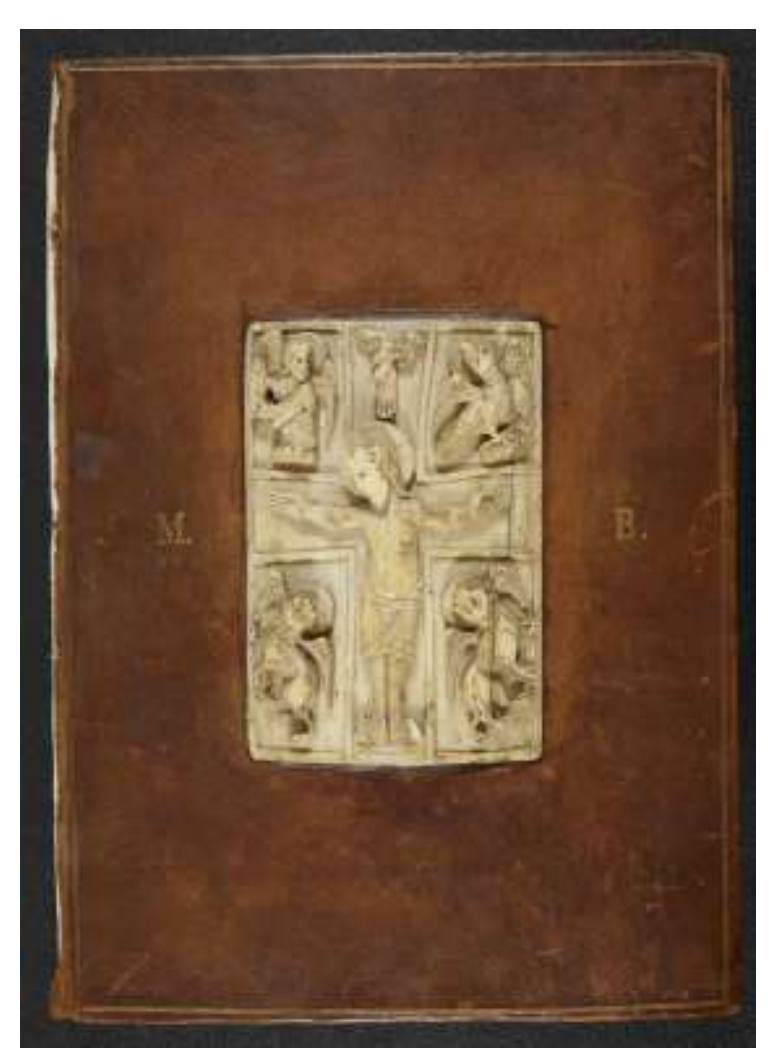

Fig. 9: German book binding, nth century.

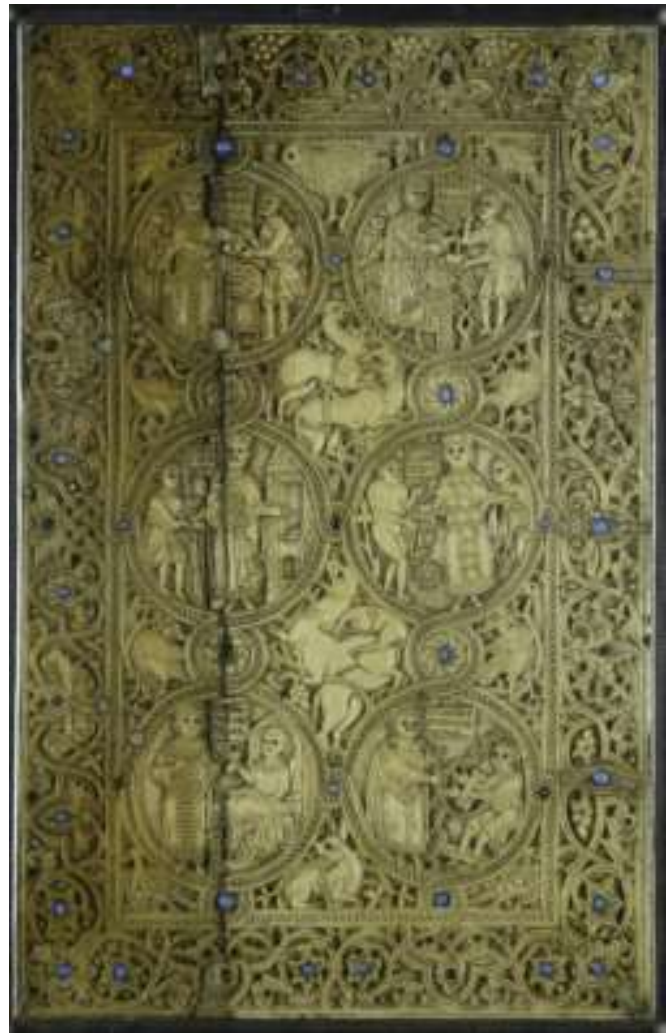

Fig. 10: Italian binding, 12th century.

Figure 11 is a German binding from 13th century, a treasure binding with a metal cover from the court of Emperor Lothan at Aachen. It has wooden boards covered with brown leather and dark red silk; four strips of parchment inside the front and back covers. Silver corner guards and silver clasps on red velvet bands; large silver-gilt medallion with a bearded and moustached head in profile wearing a helmet. Figure 12 is an Egyptian binding of the Holy Quran from the 14th century with goatskin, tooled in gold geometric design, from the Mamluk period.

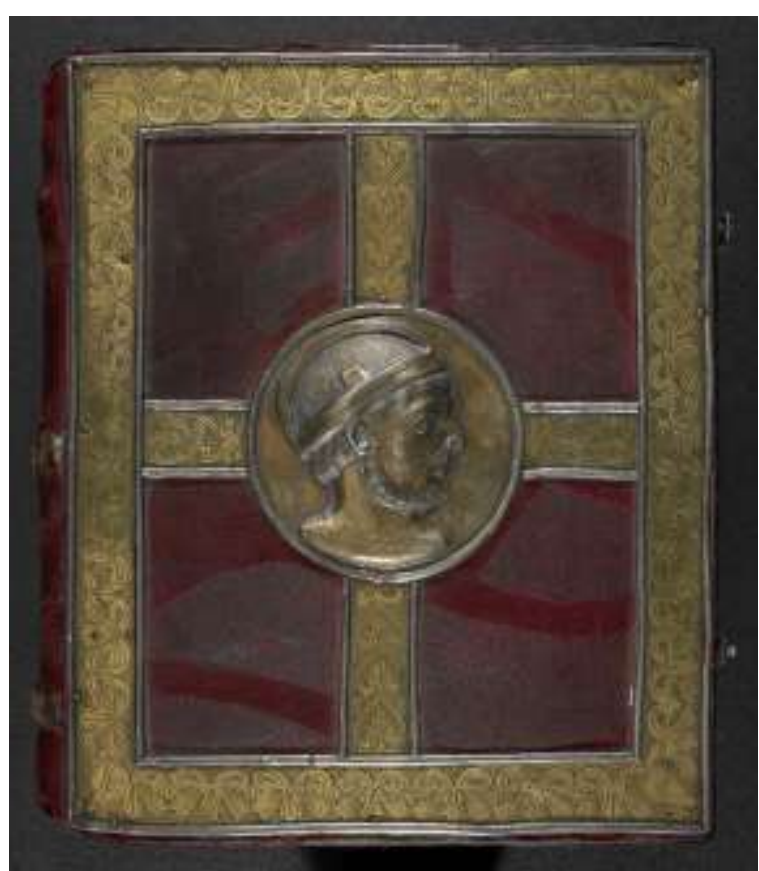

Fig. 11: French binding, 13th century.

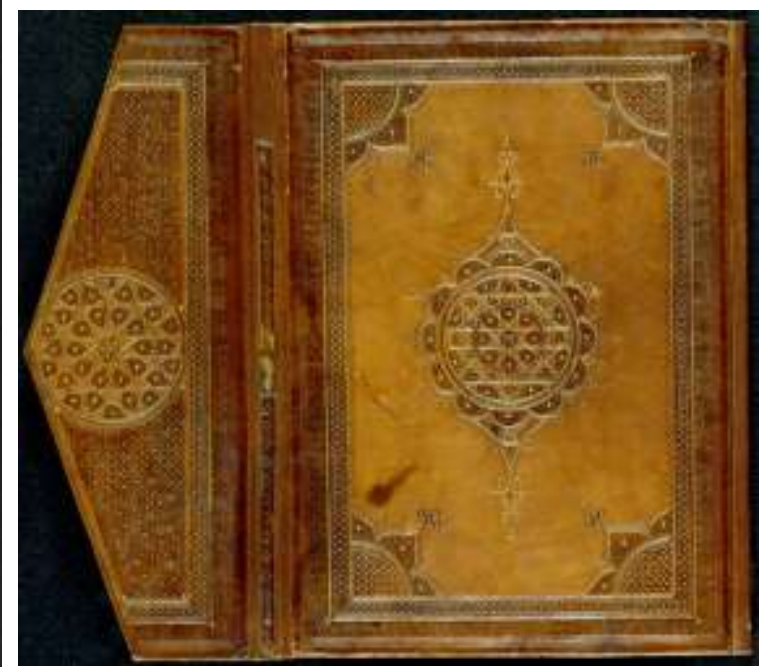

Fig 12: Egyptian binding, 14th century. 
9 | Art of the book: a brief history of decorative book binding

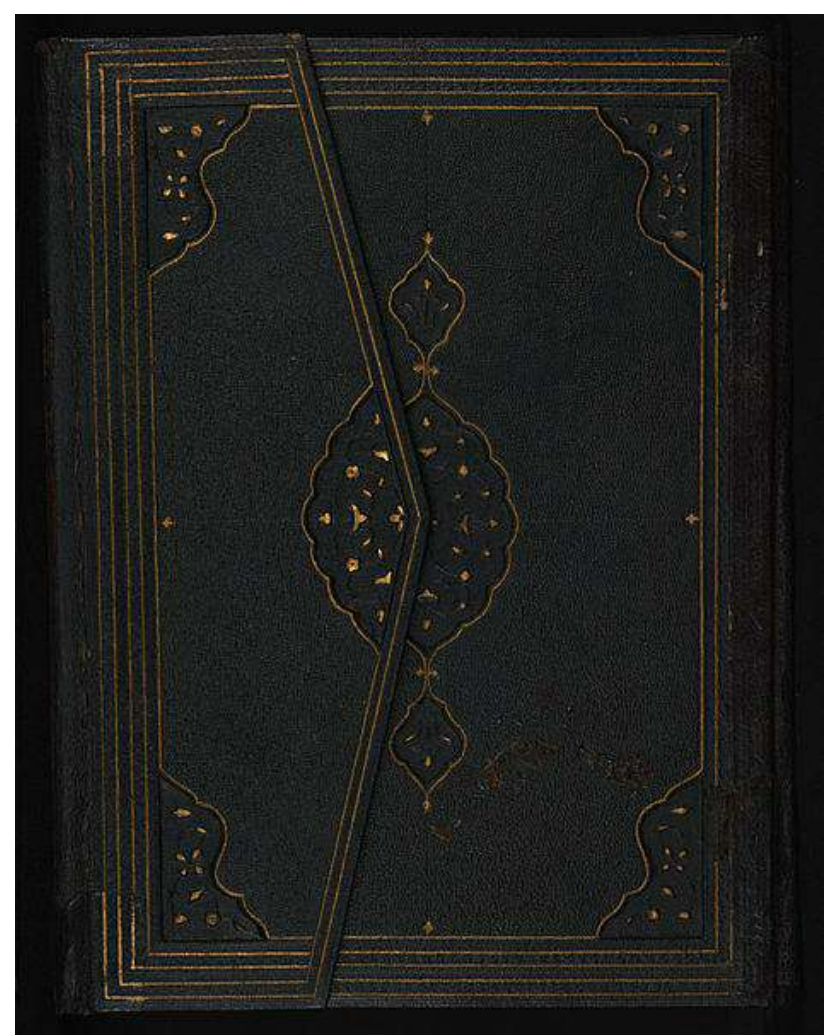

Figure 13: Persian binding, $14^{\text {th }}$ century.

Figure 14 is a German binding from the 15th century with pigskin having an allover vegetal design in panels. The traces of clasp in the binding can be seen. Figure 15 is a German binding using calf leather from the 15th century, tooled in gold with panel design and a metallic centre.

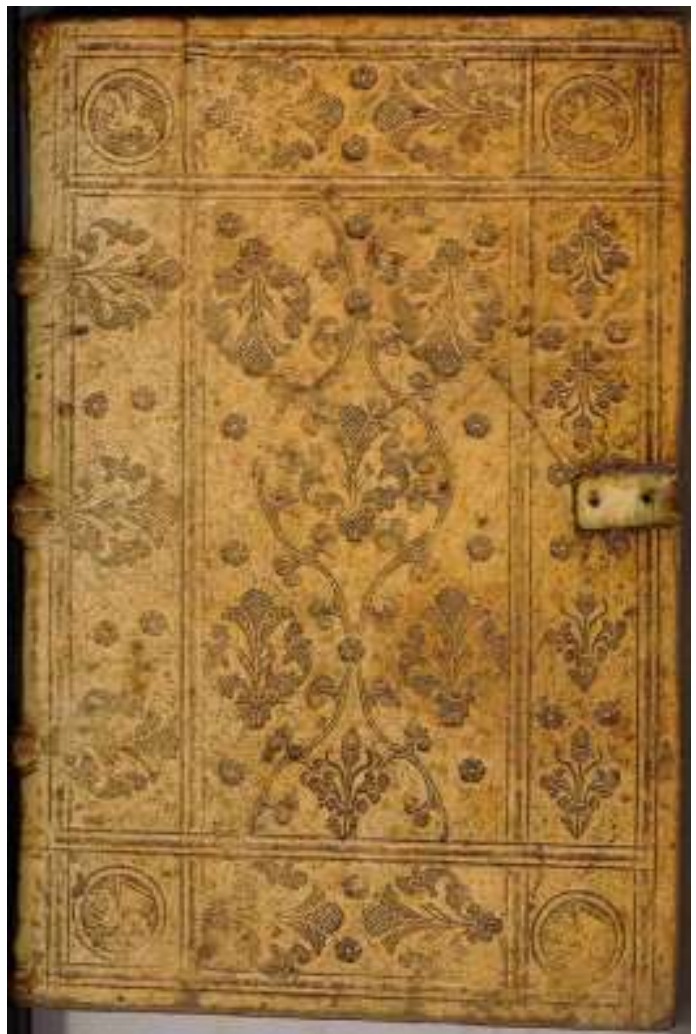

Fig. 14: German bookbinding, 15th century.

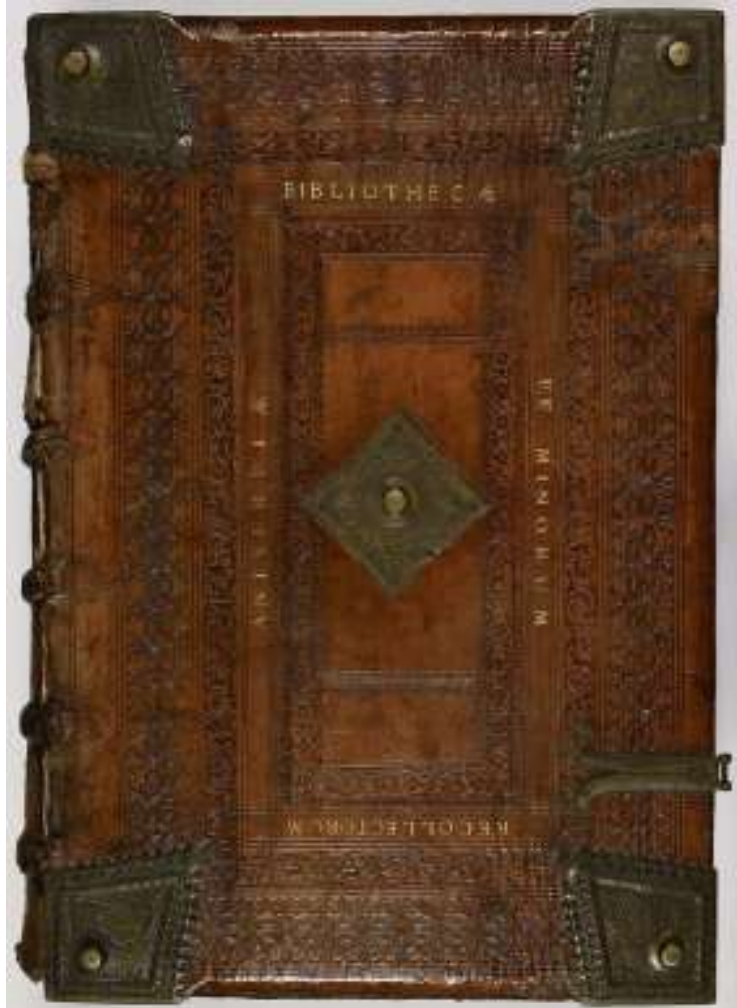

Fig.15: German bookbinding, 15th century. 
The codex is the precursor to the book and is attributed to the Coptic Church. Early Christians carried this binding technique via Egypt across the world. Each region added its own character and the book structure and decorative style evolved over time and place. The Islamic codex used the codex to record and share the Holy Quran. The codex or bound book is called Mushaf. Contents were kept safe between two rough boards to enclose the sections of the Holy Quran were written; similar to Coptic binding in which leather covers were used. Further, the Islamic codex had very high standards of decoration using specialised blind tools and stamping techniques. patterns such as eight-pointed star, twisted rope, ringlets, rosettes, florals were made on leather covers of books. Once the leaves of a book were arranged, it was given clasps or thongs in leather to wrap around in order to close the book. The Islamic world took to papermaking in place of parchment centuries earlier to Europe. There also existed 'box books' which had walls on the sides too. These are now mostly broken off from the specimens but must have proved useful when books were transported through trade routes in North Africa to Spain following Muslim conquests beginning in the 7 th century. Art of binding was known to the Islamic community by the 7 th century. Early Islamic bindings had covers with leather applique work, repousse work, inlaid fretwork, laced, stamped or punched work, tooled work, incised and punched work and painted binding covers. The end papers were also beautifully decorated.

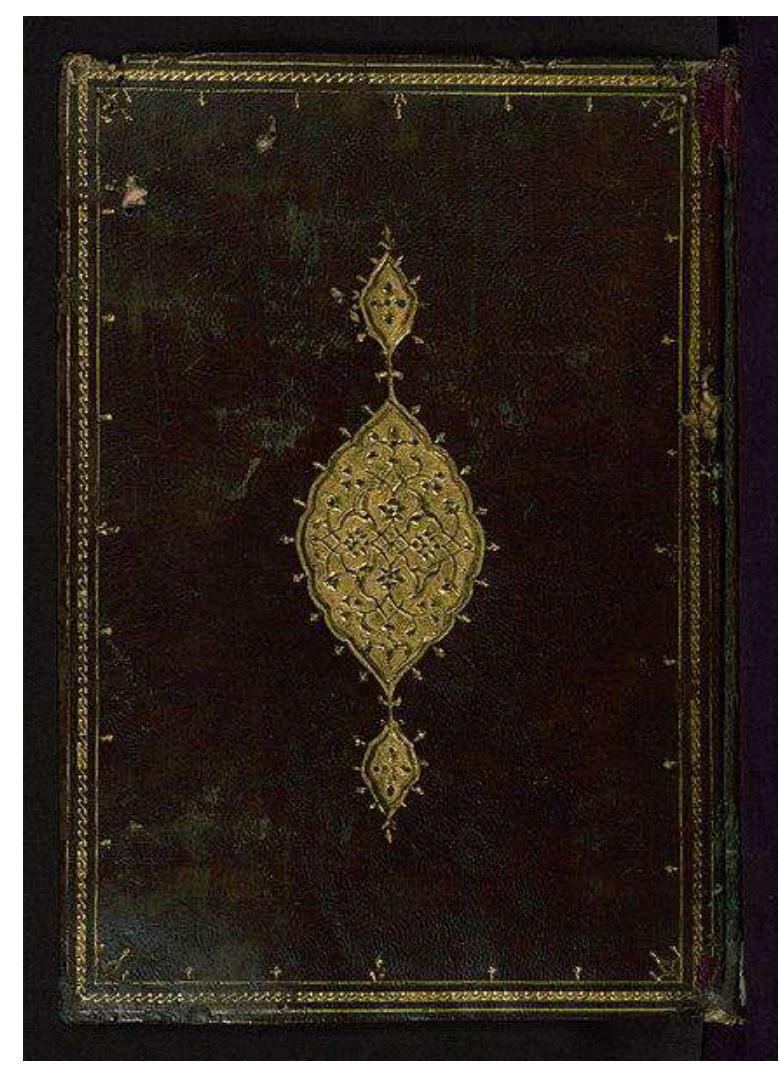

Figure 16: Persian book binding, $15^{\text {th }}$ or 16 th

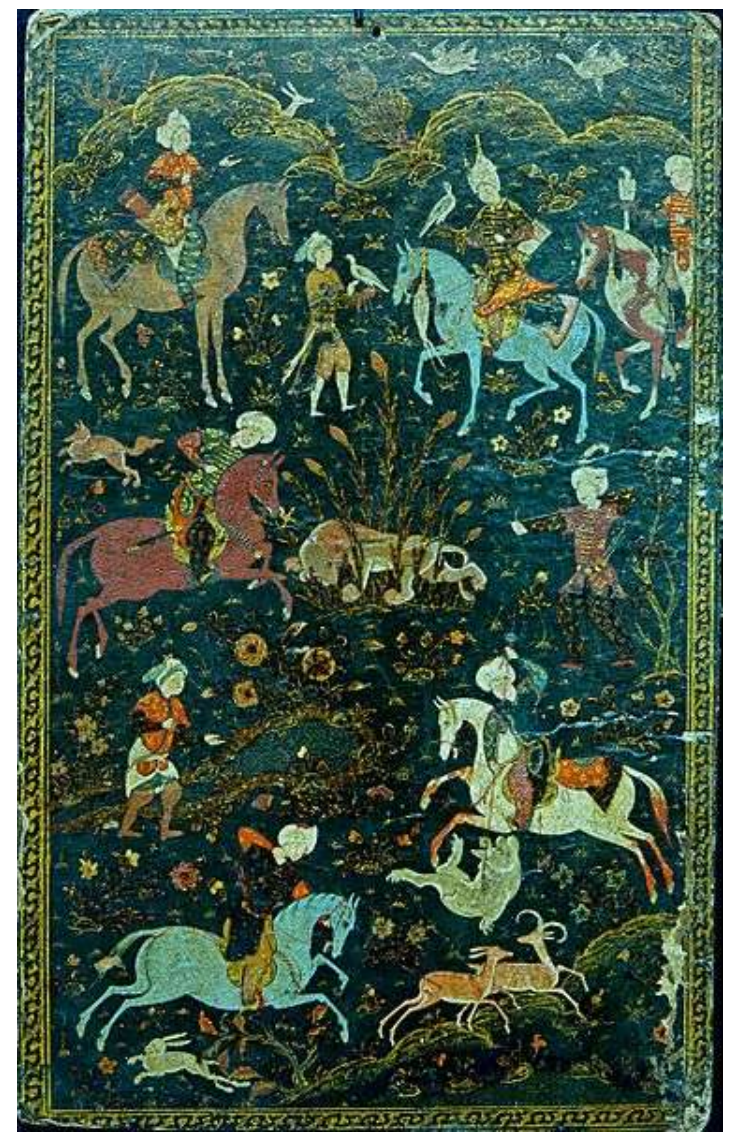

Figure 17: Persian binding, 16th century. century.

Pasteboards were used replacing earlier wood from the 1oth century for covers which were attached to the main text by the process of case binding, making a case separate from the text block and attaching the two parts with adhesive or lacing through with thread or pieces of leather. A library was established around 1420 by Baisunghar Mirza, grandson of Timur, who was a patron of of the arts, encouraged miniature painting which changed book covers into an elaborate art from. Innovation in Persia also influenced European bindings. Bindings have 
been found in mosques like the Great Mosque of Kairovan in Tunisia and Great Mosque of Sana's at Yemen.

Figure 16 is a binding with dark brown goatskin with gold from 15th/16th century having red leather doublures. Figure 17 is a lacquered board from 16th century with animal and human figures from Persia.

Figure 18 is an empty cover of a Persian binding using a lacquered board, painted with figures and designs. The codex bound in the Deccan, India in Figure 19 was formerly in an accordion format, and the multicolor flexible cloth hinges on the leaves are still visible. It was later rebound in a brown goatskin binding with a central lobed oval.

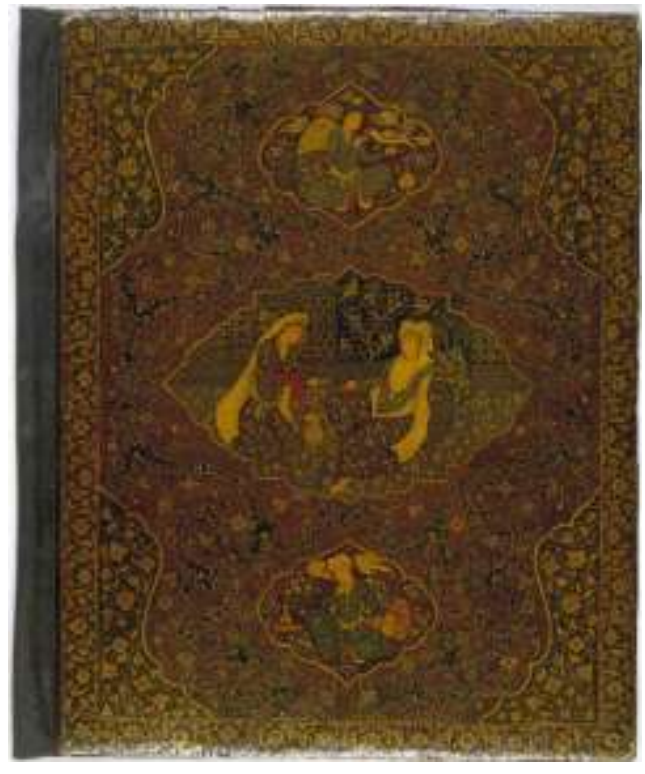

Fig 18: Persian bookbinding, 17th century.

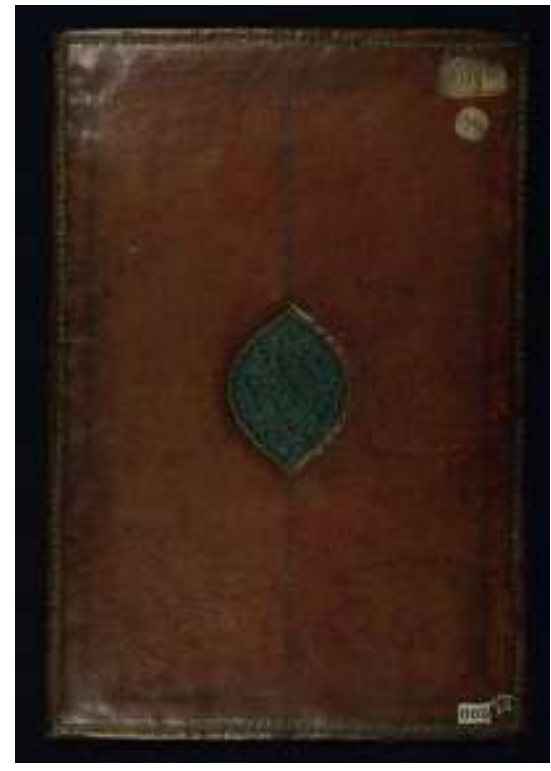

Figure 19: Deccan book binding, late $18^{\text {th }}$ century.

Figure 20 is a lacquered Persian binding from the 18th century and Figure 21 is an empty cover from the 19th century, the cover material being leather both having with floral or bird motifs. Figure 22 is a 18 th century lacquered binding with beautiful floral paisley design within ornate borders from Kashmir.

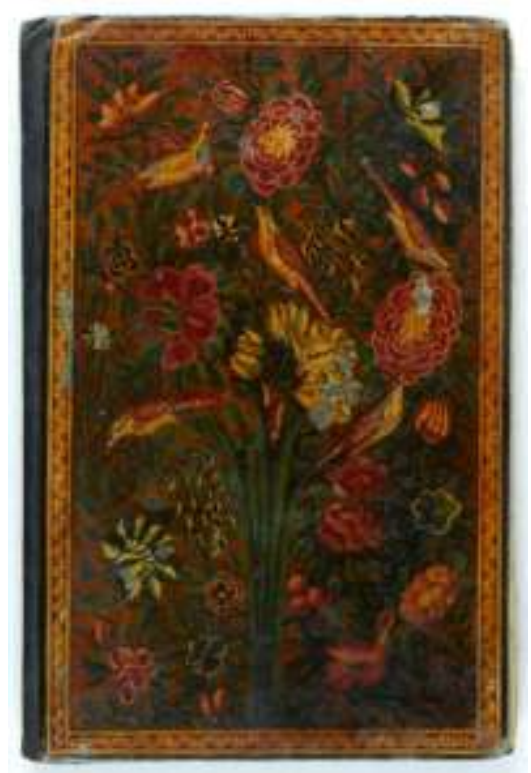

Figure 20: Persian lacquer binding, 18th c.

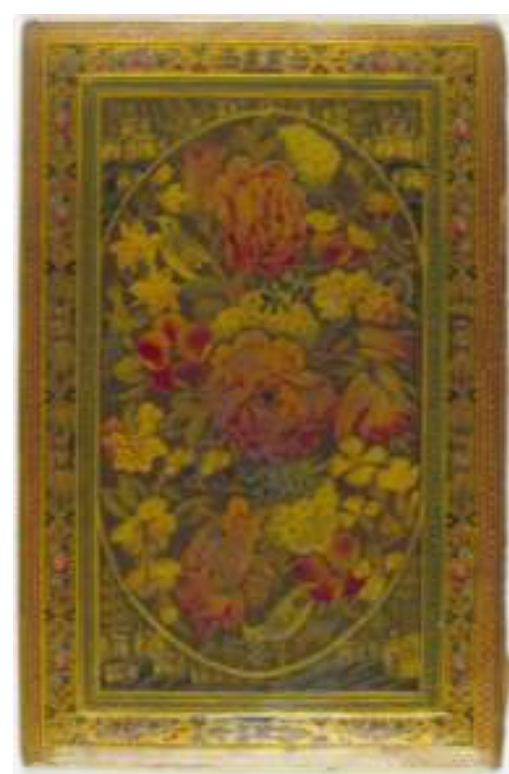

Figure 21: Persian book binding, 19th c. 


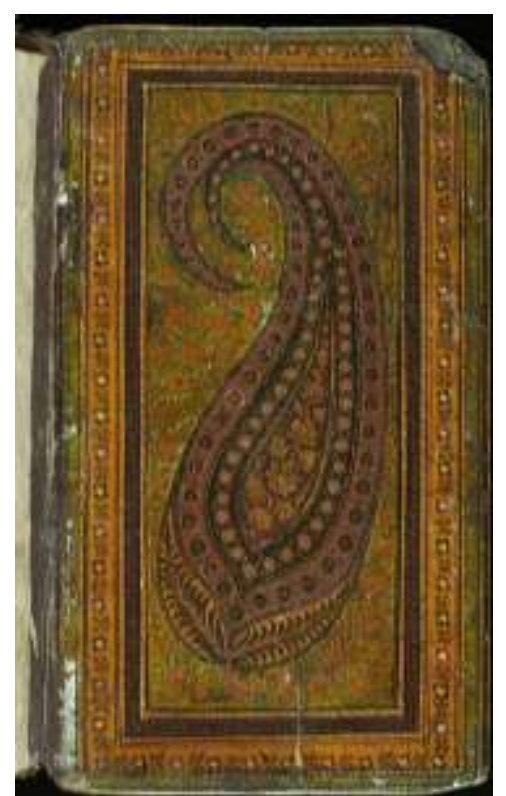

Figure 22: Kashmiri lacquer binding, $18^{\text {th }}$ century.

Figure 23 below is a binding from Turkey, with leather with stamped and gilded decoration. Figure 24 is a Persian lacquered cover with figures of trees and animals, from the 16 th century. Figure 25 is a binding from 17th century Persia with opaque watercolour and gold on leather of a floral pattern.

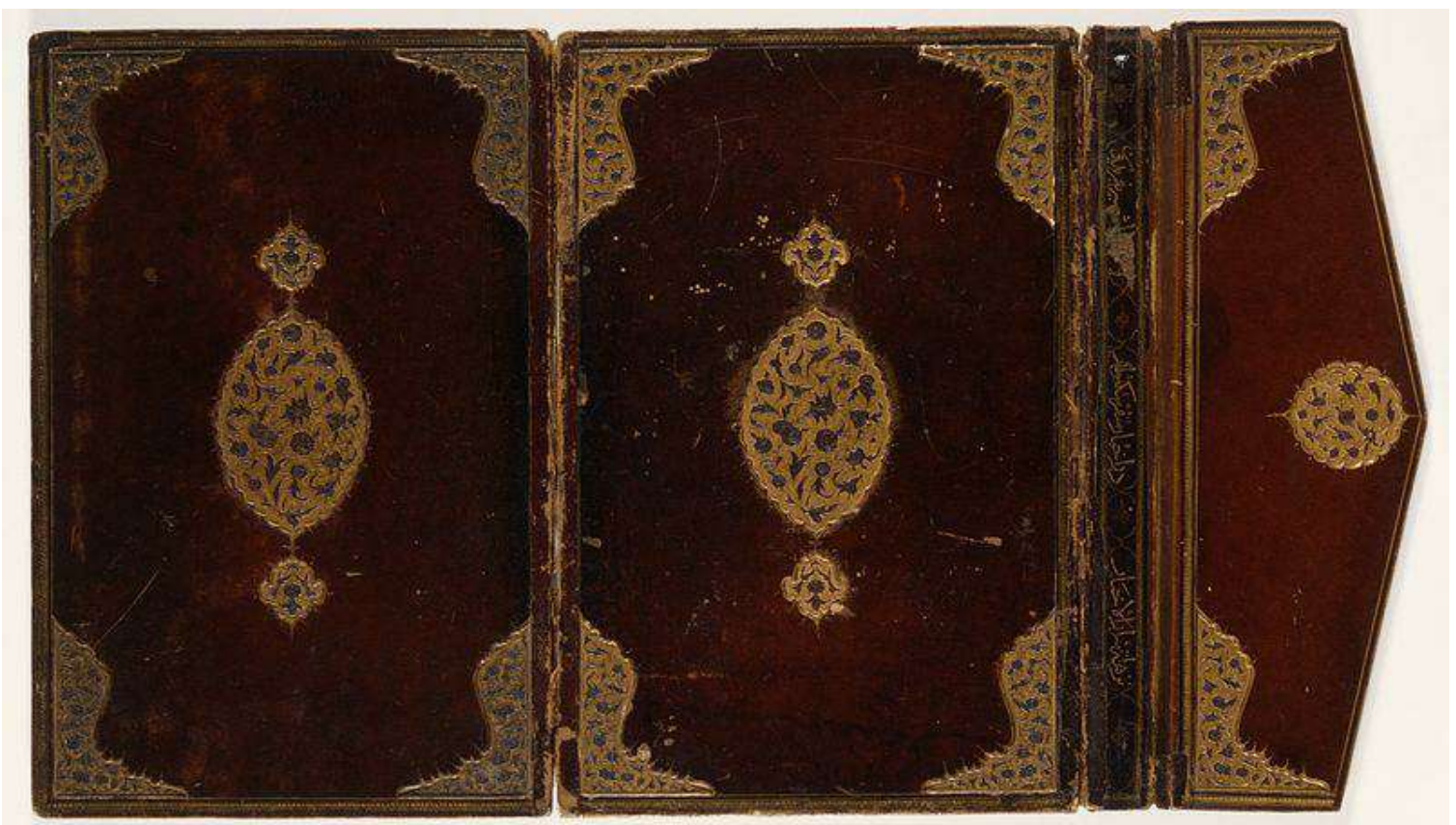

Figure 23: Turkish book binding, $16^{\text {th }}-17^{\text {th }}$ century. 


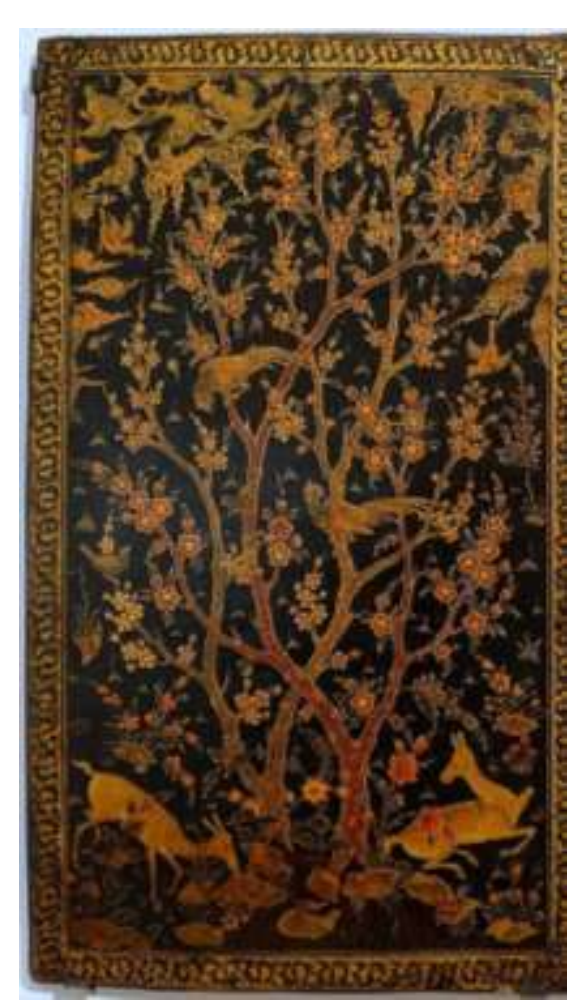

Figure 24: Persian binding, 16th century.

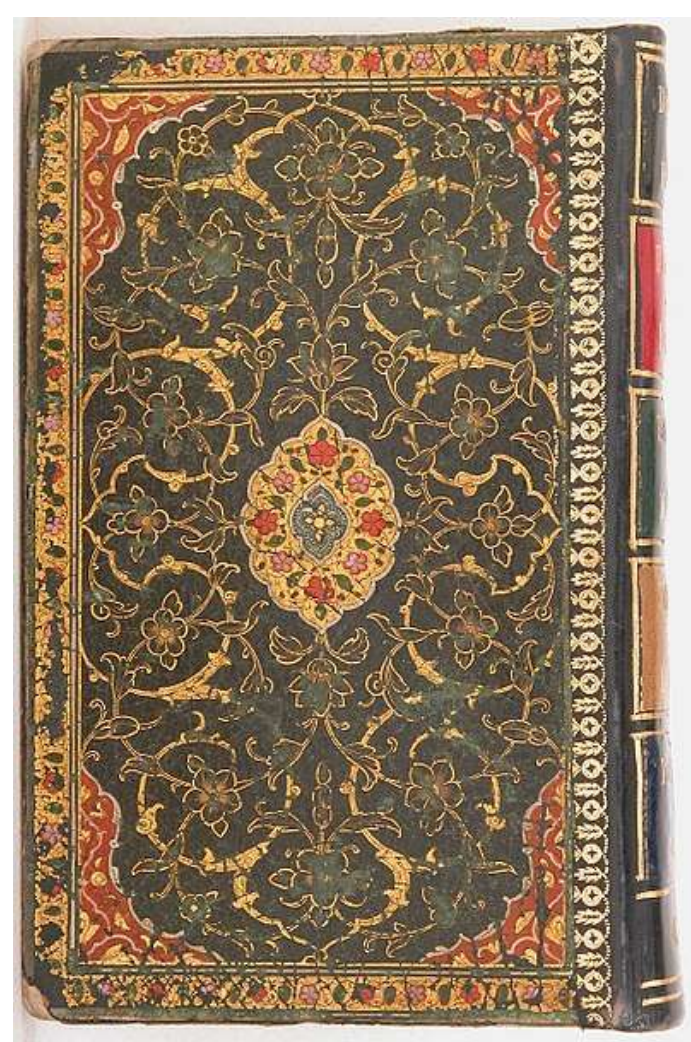

Figure 25: Persian binding, 17th century.

The art of book binding in Europe had influences of Central Asia. English bindings had wooden boards covered with calf leather with decorative motifs of birds and animals and had leather clasps. Venetian bindings showed Greek influence and used olive green morocco leather with raised headbands above the height of the rims of the sides at top and bottom and also leather clasps were used. French binding used red maroon morocco over wooden-boards, leather clasps too. Gothic decoration was seen. Grolier is a famous name of the time for whom bindings were made. Floral and leafy tools were used for creating designs. It may be mentioned here that printing was introduced in Europe in the 15th century and smaller books bound in calf or goatskin embellished with large panel stamps in blind were produced.

Italian bindings used red morocco and had endpapers like the others already mentioned. Aldus Marutius was an Italian printer from Venice who got his books bound in dark Morocco with a knot and small dolphins in blind and gold tooling. Medallions too were found on the covers. Many Italian bindings were made for Popes and Cardinals. The art of gold tooling on leather had happened in Italy too. Thomas Berthelet, royal binder to Henry VIII of England, practised this. During 15th and 16th century in England books were also bound in velvet and satin set with enamel or embroidered.During the rule of Edward IV, many English books were embellished with heraldic designs which continued during the Tudor period. William Caxton (1422-1491) was a respected printer and binder of the 15th century. Samuel Mearne and his sons Charles and Samuel Jr made the 'cottage' binding design popular; rectangular border on cover with triangles at corners, which was done from the 1600 upto the 19th century.

The French bindings used inlay technique with different coloured leathers. Exclusive bindings were made for Henry II of France. Spanish binding in early $17^{\text {th }}$ century used calf leather, had endpapers and used tools for design making. Some bindings have piercings on the vellum with silk below. English binding in the $17^{\text {th }}$ century used morocco, had endpapers and used floral tools. Late $17^{\text {th }}$ century English binding used red morocco with coloured patterns and had marbled endpapers. English binders were good at blind stamping without use of gold. 
Figure 26 is a binding with clasps, from Italy from the 16th century in goatskin, tooled in gold with decorative design. Figure $\mathbf{2 7}$ is also an Italian binding with goatskin leather and tooled in gold from the 17th century.
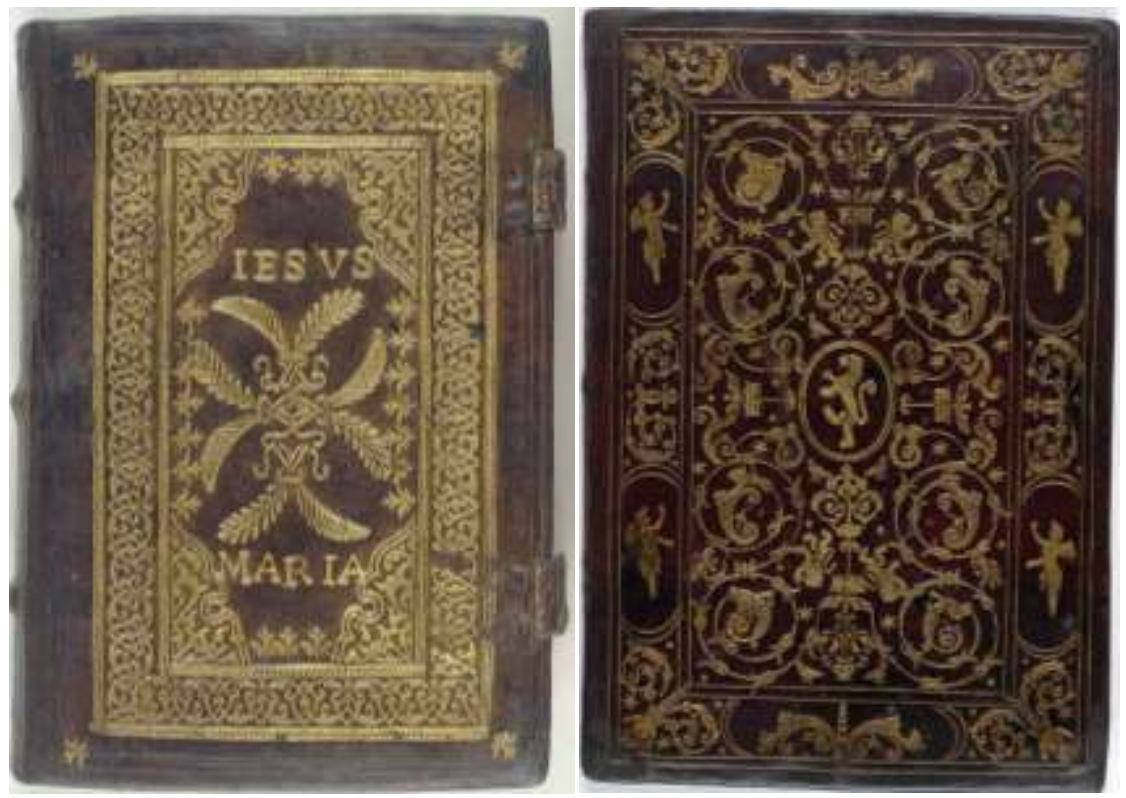

Figure 26: Italian binding, 6 $^{\text {th }}$ century. Figure 27: Italian binding, 17th century.

In the $18^{\text {th }}$ century French binders used dark blue morocco inlaid with different colours with white end papers. Up to mid $18^{\text {th }}$ century red morocco inlay with green was seen in England and Ireland. Marbled endpapers and bands were common. In modern times decorative book binding is done for limited edition luxury coffee-table type books mostly. Figure 29 and 30 is for "Grolier" type of binding, tooled in gold with goatskin leather from the 16th century. Jean Grolier was the treasurer of France in 1545 and a great collector of fine books, books bound for himself with his legend upon them. Figure 31 is French binding from the 16th century with repetitive floral motif in ovals, tooled in gold. Figure 32 has an embroidered velvet book cover in floral design made in 17th century in England. During this time fine binding mostly in morocco happened in England and John Gibson was a favourite binder. Books were bound for the royalty. 16th and 17th century France had master craftsmen like Nicholas Eve who did work for Henry III. Clovis Eve was also a talented binder-artist.

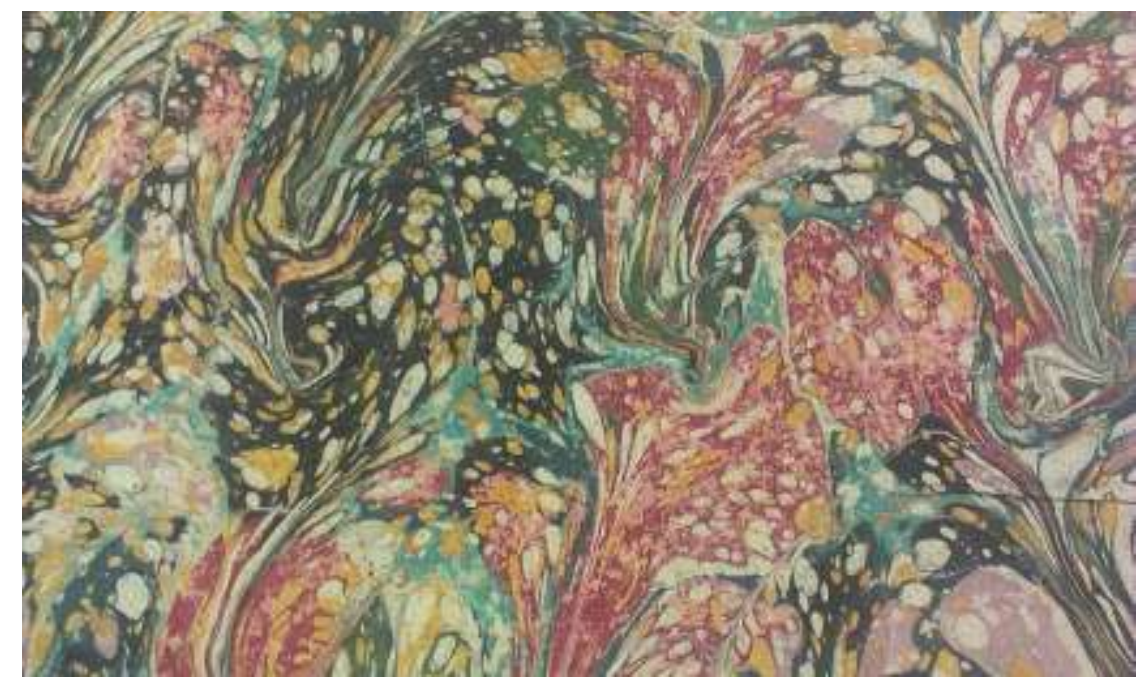

Figure 28: Marbled paper, France, $17^{\text {th }}$ century. 
15 | Art of the book: a brief history of decorative book binding

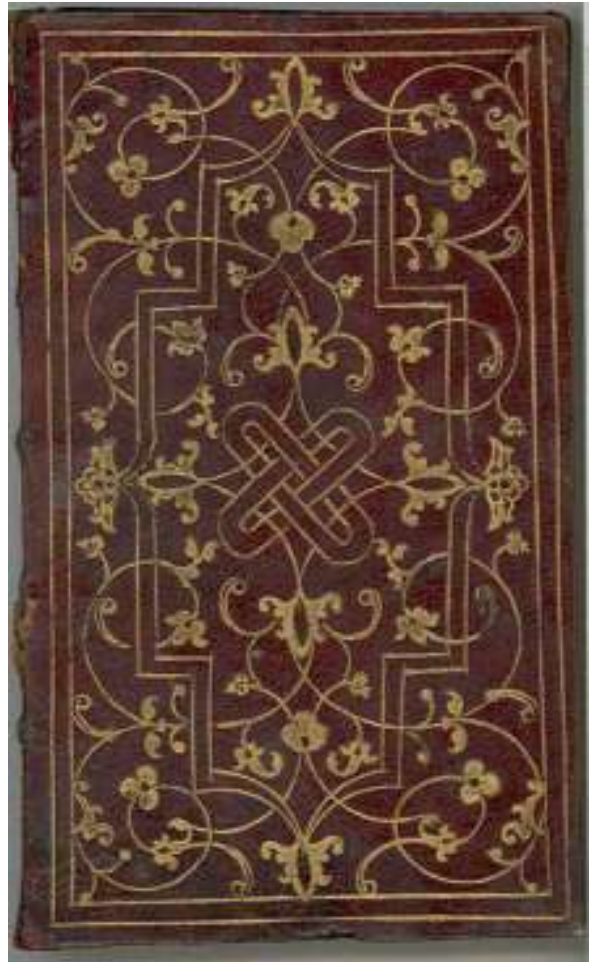

Figure 29: French binding, $16^{\text {th }}$ century.

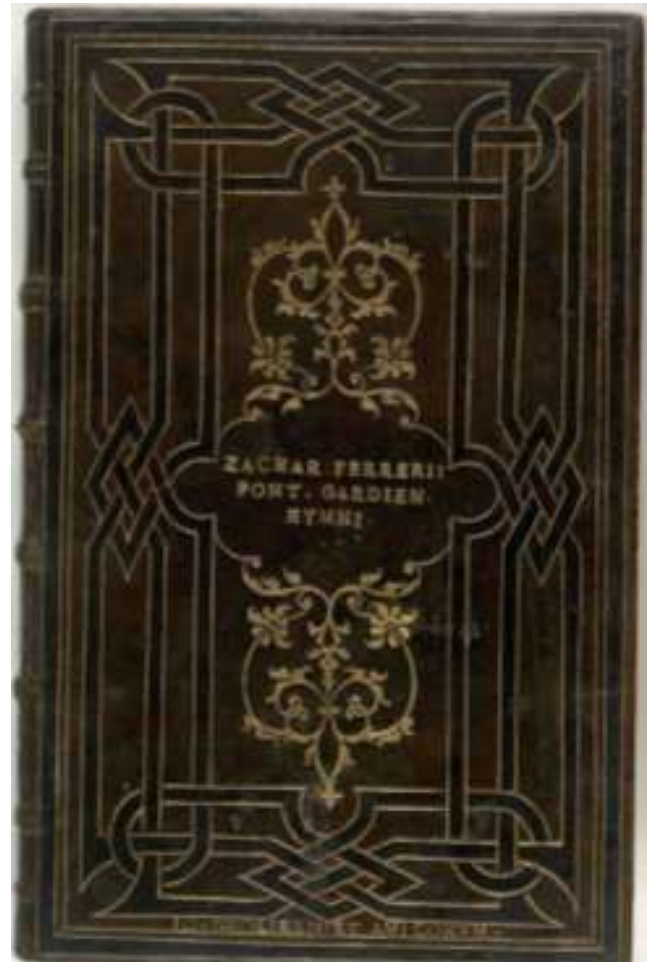

Figure 30: French binding (Grolier), $16^{\text {th }}$ century.

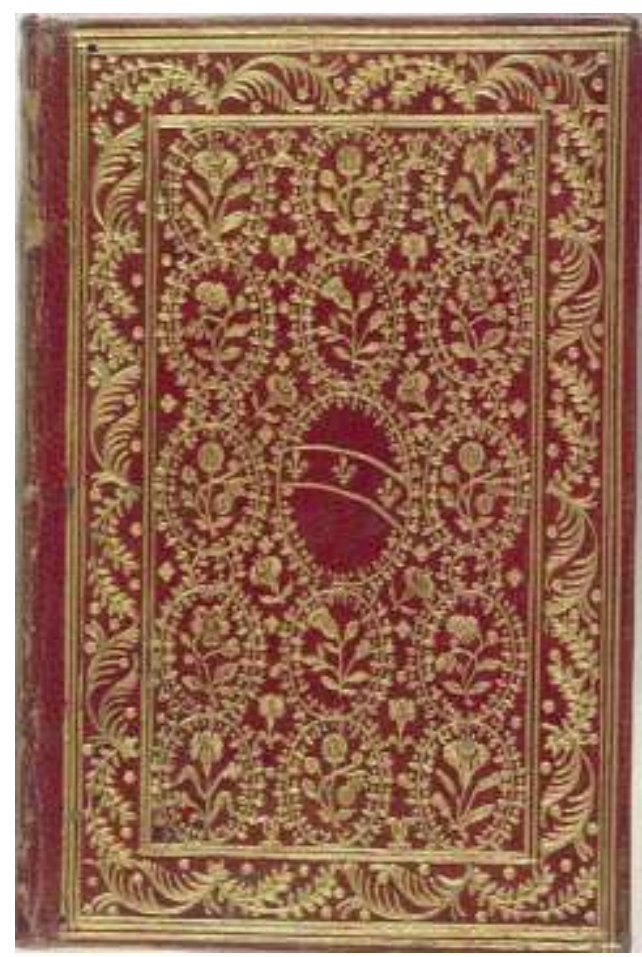

Figure 31: French binding, $16^{\text {th }}$ century. 


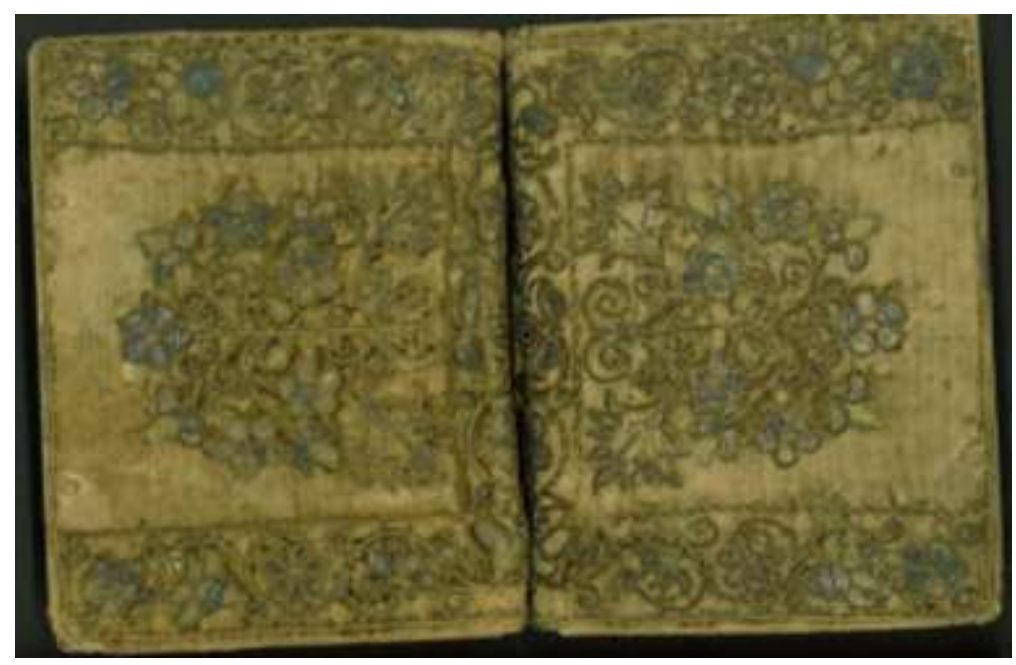

Figure 32: Embroidered book cover, 17th century, England.

Figure 33 is from 18th century England, parchment cover, tooled in gold with vegetal panel design with a floral centrepiece. Figure 34 is a cloth binding from 19th century, England, with floral motifs and ornate border.

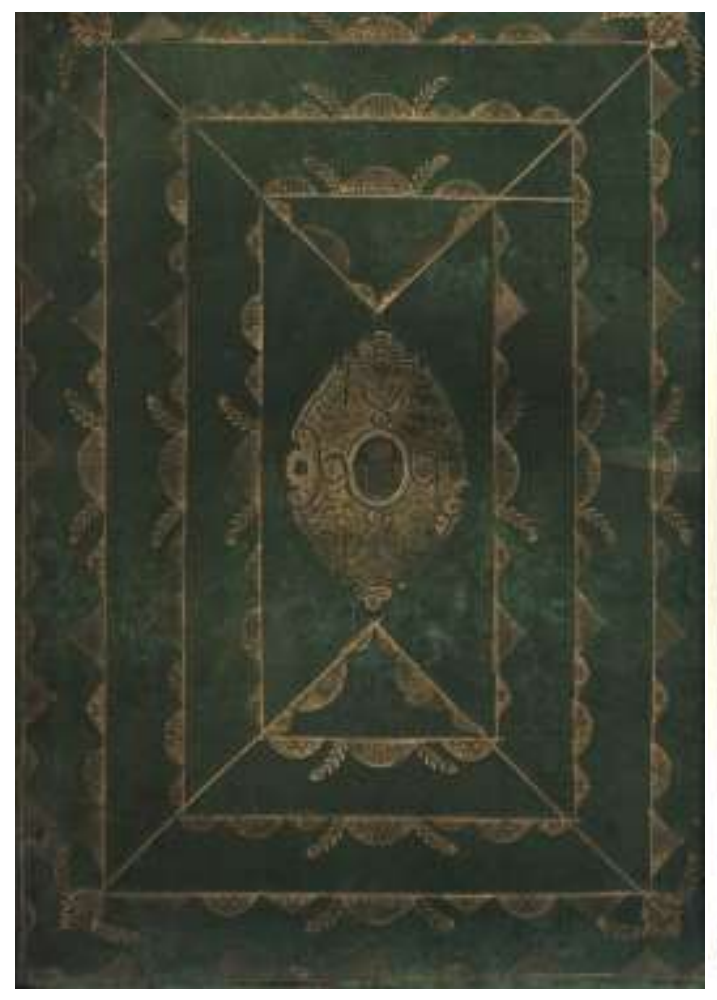

Figure 33: English binding, $18^{\text {th }}$ century.

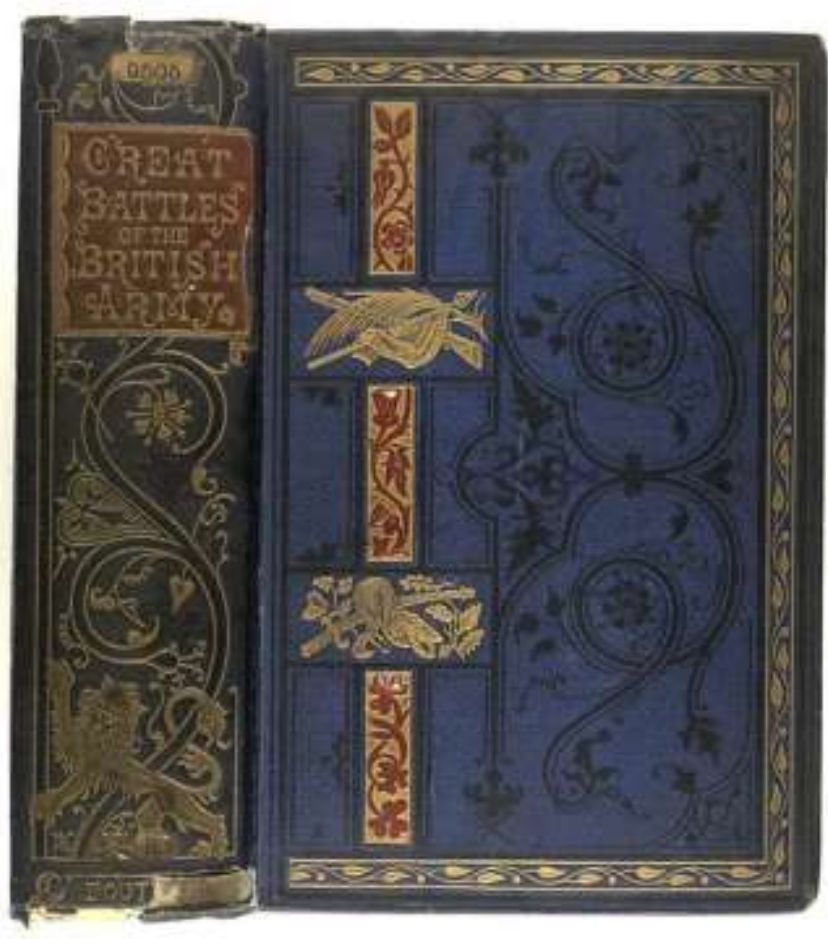

Figure 34: English binding, $19^{\text {th }}$ century.

Figure 35 is a Chinese binding from the 18th century lacquered with figure motifs, Figure 36 is a Spanish binding from the 19th century in calf leather, tooled in gold in floral frame design. 
17 | Art of the book: a brief history of decorative book binding

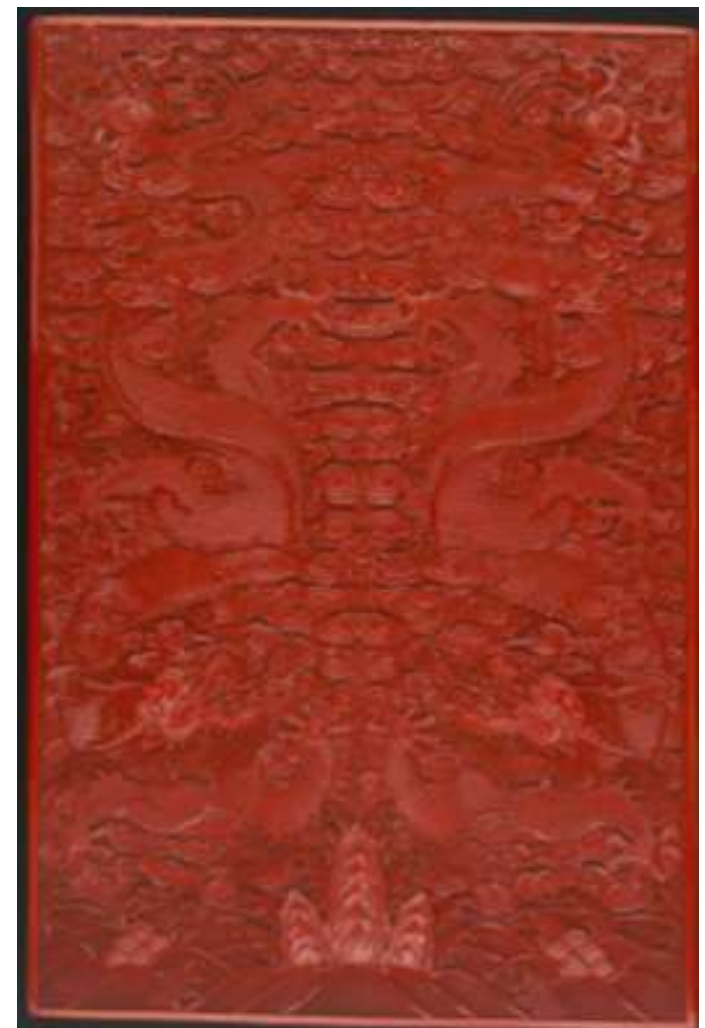

Fig.35: Chinese binding, 18th century.

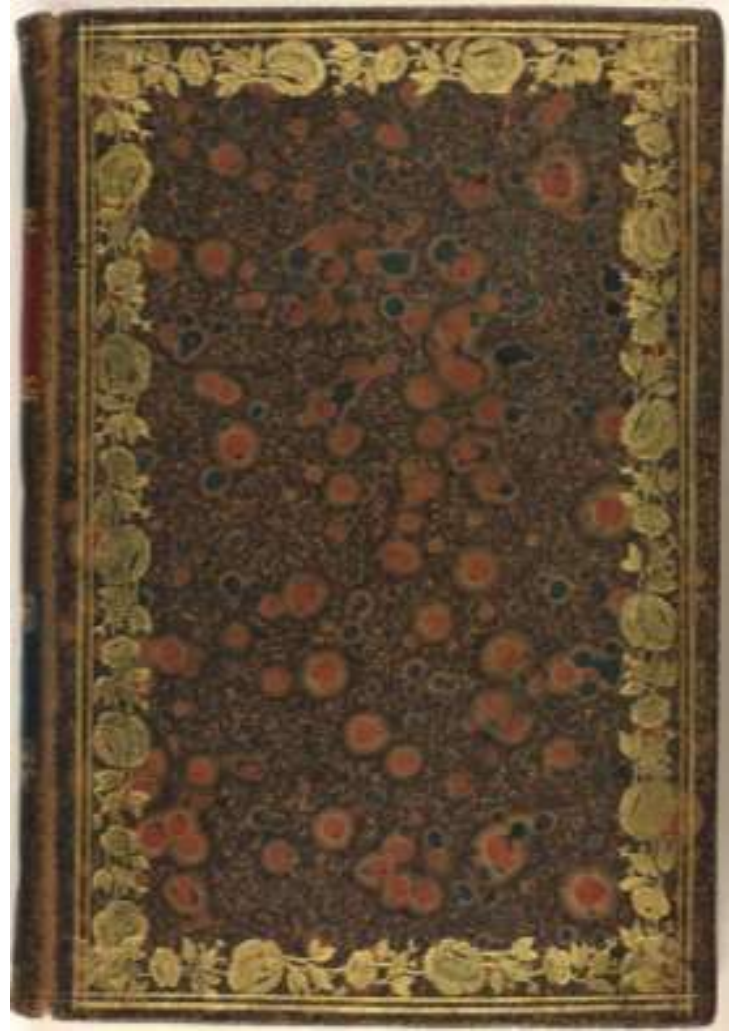

Fig.36: Spanish bookbinding, 19th century.

Figure 37 is an English doublure of a 19th century binding from England with goatskin, tooled in gold and having floral design. The doublures are onlaid in leather and free end leaves are lined with green watered silk. Figure 38 is an English binding from the 2oth century in goatskin, tooled in gold with art nouveau design all over. Figure 39 is a special edition book cover from the $21^{\text {st }}$ century.

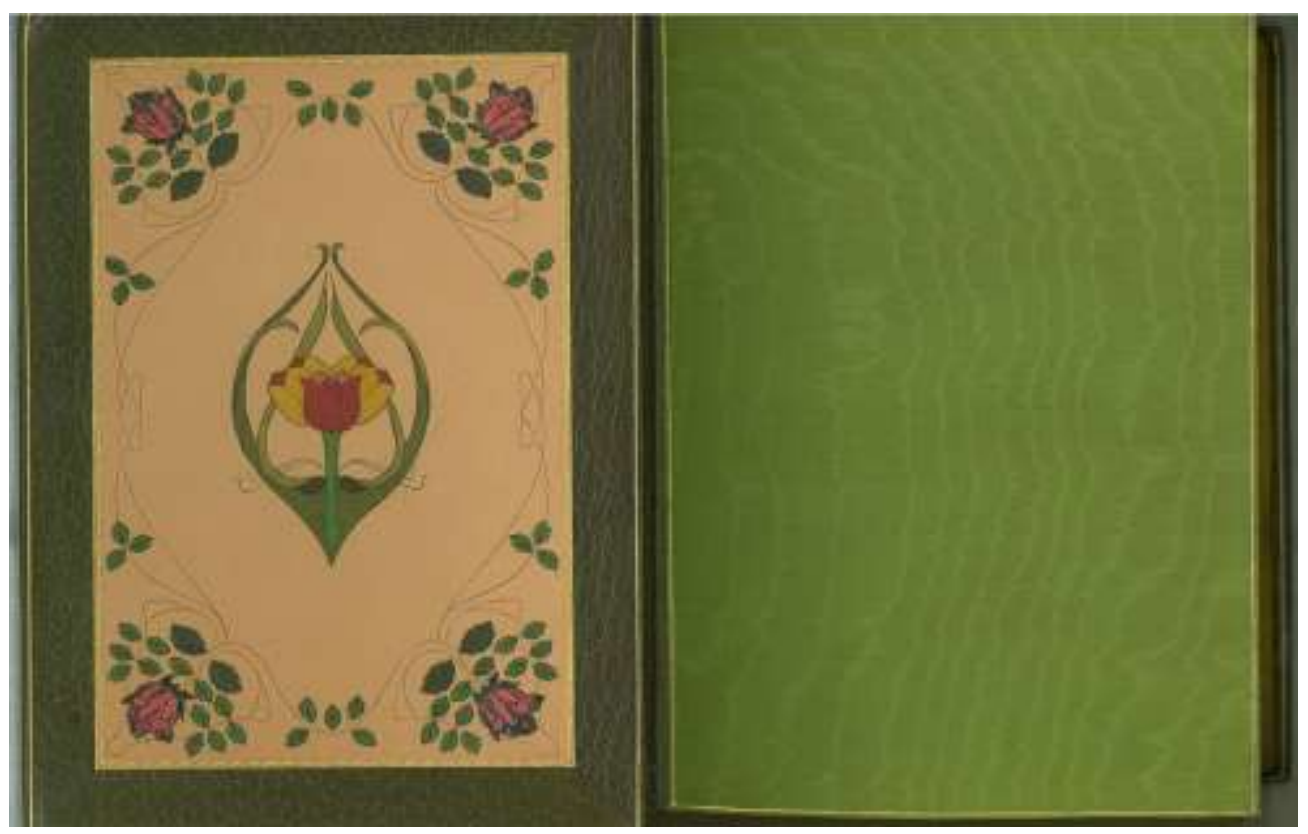

Figure 37: Doublure, England, 19th century. 


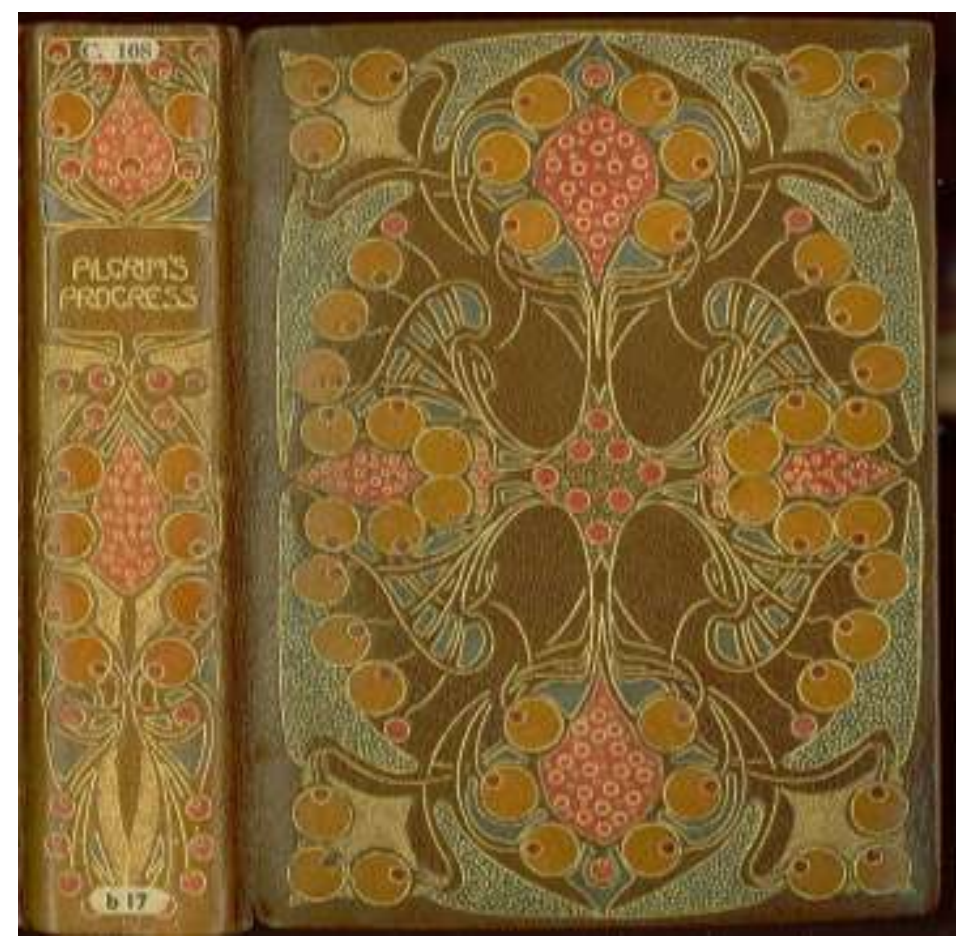

Figure 38: English bookbinding, 2oth century.

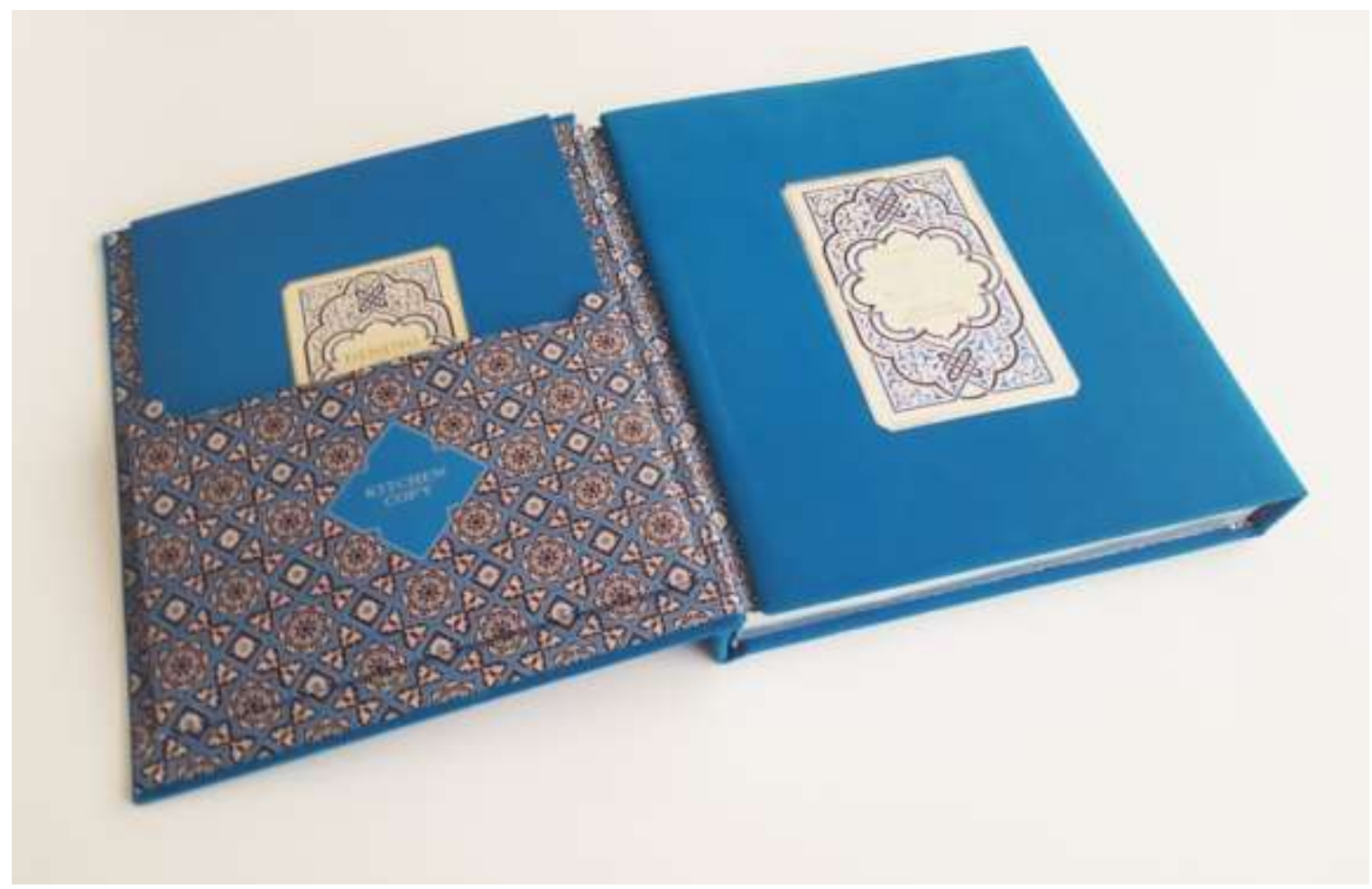

Figure 39: Book cover, $21^{\text {st }}$ century. 


\section{References and image attributions:}

1. Zaehnsdorf, Joseph William, The art of book binding, London: George Bell and Sons, 1890.

2. Wheatley, Henry Benjamin, Remarkable bindings in the British Museum, Cambridge: Cambridge University Press, 1889.

3. Loring, Andrews William \& Matthews, William, A short historical sketch of the art of book binding, New York: Strikeman and Co, 1895.

4. Hasluck, Paul. N. ed., Book Binding, London: Cassell and Company Ltd, 1926.

5. Sarre F., Islamic book bindings, London: Kegan Paul, Trench Trubner and Co. Ltd, 1923.

6. Hobson, G.D, Thirty bindings, London: The First Edition Club, 1926.

7. Mahurkar, Kamala, The art of Islamic book binding, Salar Jung Museum Bi-annual Research Journal Vol XIII-XIV, 1980-81,71-76.

8. Uniyal.C.P, The art of book binding in the Deccan: some aspects, Salar Jung Museum Bi-annual Research Journal Vol XXXV-XXXVI, 1998-99, 68-73.

9. Sharma,O.P, Some illustrated book-covers in the collection of the National Museum, New Delhi Rooplekha Volume XXXIX, Nos. 1 and 2, 1970, 44-54.

10. https://en.wikipedia.org/wiki/Bookbinding(accessed 19.9.2018)

11. http://www.ndl.go.jp/incunabula(accessed 19.9.2018)

12. http://www.artesdellibro.com/pdf/islamic_art_bookbinding(accessed 19.9.2018)

13. http://ultimatehistoryproject.com/the-islamic-codex(accessed 19.9.2018)

14. Images are via Wikimedia Commons (public domain) (accessed September 2018)

15. Image 39 via https://sunday.com.pk/mustread-dining-with-the-nawabs(accessed 19.9.2018)

The author is Librarian and Media Officer at Salar Jung Museum, Hyderabad, Ministry of Culture, Govt. of India. She has previously worked at the British Council Library at Hyderabad. She has an M.Phil in Library Science and University Diplomas in Archival Science and Museology. She is an alumnus of Osmania University, Hyderabad. In addition to Library Management and Digitisation, she does online art curatorial projects, social media related work and research. She has authored five e-books on Indian art and has an avid interest in art history. Information retrieval is her forte along with interest in emerging technologies for libraries. 